\title{
Winding Up Dissolved Law Partnerships: The No-Compensation Rule and Client Choice
}

The attractiveness of the partnership form of organization hes in its simphicity and flexibility. ${ }^{1}$ While partnership formation is typically friendly and informal, ${ }^{2}$ dissolution can be acrimonious and complex. Nonetheless, among law partnerships, dissolutions are a relatively comnon occurrence. ${ }^{3}$ Thus, lawyers frequently find themselves in courtnot on behalf of their chents, but on behalf of themselves.

Partnerships may resolve issues arising during dissolution in a nuniber of ways. Where potential conflicts are foreseeable, a detailed partnership agreement may serve to forestall litigation by allocating rights and duties among the various partners. ${ }^{4}$ As one commentator has noted, lowever, "[i]ronic though it may be, lawyers, who spend a great deal of time advising their chents of the protection and expediency of taking prophylactic measures for such a contingency, often fail to utilize similar tools for their own benefit."5 Without agreeing in advance, partners may be able to resolve frictions on the eve of dissolution by entering

1. See generally A. Bromberg, CRANe and Bromberg on Partnership $\S 2$ (1968) (recognizing malleability as perhaps the most important attribute of partnership).

2. A limited partnership, on the other hand, requires compliance with statutory standards. See generally id. $\$ 26$ at 143; H. REUSChLEIN \& W. GREgory, HANDBOoK ON THE LAW OF AGENCY AND PARTNERSHIP $\S 264$ at 434 (1979).

3. See, e.g., Brill, The Shakeout is Here: Dissension in the Ranks at Dewey, Ballantine and Donovan, Leisure, AM. LAW., July/Aug. 1983, at 1; Pollack, Partner Charges Firm Conspired to Oust Him, AM. LAw., Sept. 1980, at 14; Galante, Partner Leads Mass Exodus from L.A. Firm, Nat'1. L.J., Dec. 19, 1983, at 3, col. 1; Galante, Lawsuit Flurry Follows Dissolution of Belli Firm, Nat'1 L.J., Dec. 12, 1983, at 4, col. 3; Stewart, A Blue Chip Law Firm Comes on Hard Times After a Coup d'Etat: Donovan, Leisure Faces Risk Some Clients May Follow Top Partners in Leaving, Wall St. J., Nov. 18, 1983, at 1, col. 6; Galante, Jenkins \& Perry Feud Almost Over, L.A.' Daily J., March 17, 1983, at 5, col. 1; Simon, Howrey \& Simon Hit By Fight Over Money, Nat'l L.J., Jan. 31, 1983, at 2, col. 4; Graham, Jacksonville Partners Win Control, Lose Colleagues, Legal Times Wash., Apr. 5, 1982, at 2, col. 1; Moore, Houston's Butler, Binion Sees Biggest Split in City's History, Legal Times Wash., Feb. 15, 1982, at 1, col. 2; Graham, Progressive Ideals Put to Test at Wald, Harkrader, Legal Times Wash., Jan. 18, 1982, at 44, col. 1; Tell, Marshall Bratter Loses Seven Partners in a Rift, Nat'1 L.J., Jan. 11, 1982, at 2, col. 3; Fox, Law Firm Sues Ex-Partners for Taking Clients with Them, N.Y.L.J., Sept. 3, 1980, at 1, col. 1. See generally Gilson \& Mnookin, Sharing Among the Human Capitalists: An Economic Inquiry Into the Corporate Law Firm and How Partners Split Profits (April 1984) (Working Paper for the Law and Economics Program, Stanford Law School).

4. Obviously, not all potential sources of friction are foreseeable. Thus, disputes may arise over matters not covered by the partnership agreement, see Crum, Dissolution of a Law Partnership-Goodwill, Winding Up Profits, \& Additional Compensation, 6 J. LEGAL Prof. 277, 277 (1981). Disputes can also arise over the meaning of provisions contained in the agreement.

5. Id. at 277. 
into a dissolution agreement that allocates partnership rights and duties. However, when there is no agreeinent among the partners, courts in inost jurisdictions will apply statutory principles to resolve dissolution controversies. ${ }^{6}$ While these principles may work reasonably well in the context of ordinary commercial partnerships, the dissolution of law partnerships raises important public pohicy concerns that are ill-served by the mechanical application of statutory formulas.

In particular, disputes are likely to arise as to the rights and responsibilities of partners during the winding-up period. Under the Uinform Partnership Act, enacted in almost every jurisdiction, partners who have not wrongfully dissolved the partnership ${ }^{7}$ have a right to participate in the winding $u^{8}$ of partnership affairs. Except in the case of a surviving partner, the general rule is that no partner is entitled to compensation

6. In the absence of an agreement to the contrary, partnership disputes will be resolved according to provisions of the Uniform Partnership Act. The Act is in force in 48 states and the District of Columbia, as well as in Guam and the Virgin Islands. Only Georgia and Louisiana have not adopted its provisions. See generally H. REUSCHLEIN \& W. GREGORY, supra note 2, § 174 at 246-47. Reuschlein and Gregory, however, is somewhat dated. For a comprehensive list of the relevant statutory citations in each jurisdiction, see UNIF. PARTNERSHIP ACT, 6 U.L.A. 1 (Supp. 1985).

7. A wrongful dissolution occurs when a partner dissolves the partnership in contravention of the partnership agreement. UNIF. PARTNERShIP ACT § 31(2), 6 U.L.A. 376 (1969); CAL. CoRp. CODE $\S 15031$ (2) (West 1977). In such a case, each wrongfully dissolving partner may be liable for damages resulting from the breach of the agreement. UNIF. PARTNERSHIP ACT $\S 38(1), 6$ U.L.A. 456-57 (1969); CAL. CoRP. CODE § 15038(1) (West 1977); see, e.g., Burnstine v. Geist, 257 App. Div. 792, 793, 15 N.Y.S. 2d 48, 49-50 (1939) (dissolution of law firm prior to contract term). Furthermore, the partners who have not wrongfully caused the dissolution may preserve the value of the business by electing to continue the partnership for its term by themselves or jointly with others. To make this eleetion, the innocent partners must (1) pay or secure to the wrongfully dissolving partner the value of his interest in the partnership at the time of dissolution (ininus any damages for the breach), and (2) indemnify the wrongfully dissolving partner against all present or future habilities. UNIF. PARTNership ACT § 38(2)(b), 6 U.L.A. 456 (1969); CAL. CoRP. CODE $\S 15038(2)$ (b) (West 1977). See generally A. BROMBERG, supra note 1, $\$ 75$ at 426-30; H. ReuschleIN \& W. GRegorY, supra note 2, § 229G at 348. Thus, the Uniform Partnership Act distinguishes between the power and the right to dissolve in contravention of the agreenent. $A$ partner has the power to dissolve, but not the right. A. BROMBERG, supra note 1, § 75(a) at 427-28. The actions of the dissolving partner need not be explicitly "in contravention of the agreement" in order to be deemed wrongful for purposes of invoking the danage and continuation provisions of $\S 38$. Actions that substantially impair the carrymg on of the busimess may result in a "wrongful" dissolution. See, e.g., Vangel v. Vangel, 116 Cal. App. 2d 615, 623, 254 P.2d 919, 924 (1953), affd in part, rev'd in part, and remanded, 45 Cal. 2d 804, 808, 291 P.2d 25, 26, 55 A.L.R. 2d 1385 (1955) (excluding copartners from manageinent constituted wrongful dissolution); A. BROMBERG, supra note $1, \S 75(\mathrm{~d})$ at 430 . Furthermore, a dissolution in bad faith may be deemed a wrongful dissolution. See infra text accompanying notes 26-28.

8. The Uniform Partnership Act distinguishes between "dissolution" and "winding up." "The dissolution of a partnership is the change in the relation of the partners caused by any partner ceasing to be associated in the carrying on as distinguished front the winding up of the business." UNIF. PARTNership Act § 29, 6 U.L.A. 364 (1969); CAL. CoRP. Code § 15029 (West 1977).

Winding up refers to handling partnership affairs with a view toward termination, or coinpleting transactions unfinished at dissolution. Thus, dissolution does not terminate the partnership. On the contrary, "[o]n dissolution the partnership is not terminated, but continues 
beyond his or her partnership interest for services rendered during the winding-up period of a dissolved partnership. ${ }^{9}$ The results of this nocoinpensation rule are equitable when the burden of winding up the partnership affairs falls on each partner in proportion to his or her partnership interest. In the context of a law partnership, however, the work required to complete executory contracts often will fall disproportionately on the partners. Consequently, soine partners will be required to spend a greater ainount of time winding up the unfinished business of the dissolved partnership than others. ${ }^{10}$ In this event, the no-coinpensation rule leads to inequitable results whenever the division of partnership profits is not proportional to the work load of some partners during the winding-up period.

This Comment argues that the inequities created by the no-coinpensation rule in such a situation may, in turn, lead to lock-in and lock-out. Lock-in occurs when a partner would like to dissolve a partnership in good faith but is dissuaded froin doing so due to the econormic disincentives caused by the no-coinpensation rule. For example, a partner who must spend a disproportionately large amount of time winding up the unfinished partnership business in return for a disproportionately small share of the revenues generated by the partners during the winding-up period might feel "locked" into the partnership against his or her will. ${ }^{11}$

Lock-out occurs when a dissatisfied partner dissolves the partnership in good faith, but is unable or unwilling to continue representing a foriner chient on a matter pending at dissolution, typically where the amount of work involved in completing the case is disproportionate. ${ }^{12}$ The partner who completes such a case is not entitled to compensation in excess of his partnership draw regardless of the annount of time involved, because a case pending at the time of dissolution is considered the "unfinished business" of the dissolved law partnership. ${ }^{13}$ Consequently, the no-compensation rule may discourage a dissolving partner froin repre-

until the winding up of partnership affairs is completed." UNIF. PARTNERSHIP ACT § 30, 6 U.L.A. 367 (1969); CAL. CORP. CODE $§ 15030$ (West 1977).

9. The Uniform Partnership Act states:

Unless otherwise agreed the partners who have not wrongfully dissolved the partnership or the legal representative of the last surviving partner, not bankrupt, has the right to wind up the partnership affairs; provided, however that any partner, his legal representative or his assignee, upon cause shown, niay obtain winding up by the court.

Unif. PARTNERShIP ACT § 37, 6 U.L.A. 444 (1969); CAL. CorP. Code § 15037 (West 1977). Section 18(f) states: "No partner is entitled to renuneration for acting in the partnership business, except that a surviving partner is entitled to reasonable compensation for his services in winding up the partnership affairs." UNIF. PARTNERSHIP ACT § 18(f), 6 U.L.A. 213 (1966); CAL. CORP. CODE $\S 15018(f)$ (West 1977).

10. See infra text acconipanying notes 85-88.

11. See infra text acconipanying notes $106-08$ and Part II, Section $B$.

12. See infra text acconipanying notes 109-12.

13. See infra text acconpanying notes $36-47$. 
senting a chent on a matter with which he or she has developed an intimate familiarity. In effect, the chent is "locked-out" of having the matter handled by the attorney most suited for the task.

Part I of this Comment reviews the rationale for the current systein of dividing postdissolution profits and discusses the applicable background law. Part II suggests that service partnerships, and law partnerships in particular, possess unique characteristics that may render rigid adherence to the no-compensation rule inequitable. Part II explores the phenomena of lock-in and lock-out and argues that these probleins justify a reexamination of the no-compensation rule as it is applied to law partnership dissolutions. Part III proposes and compares two alternative niodels capable of solving these problems. Part IV concludes that the best solution to these problems is to compensate a winding-up partner, but only to the extent necessary to correct for any disproportionality in the distribution of winding-up burdens. Recognizing the fiduciary principles governing the relations among partners, Part IV also proposes that compensation should be disallowed where a partner has dissolved the partnership in bad faith. Finally, in view of the clarity of the current statutory language, the Comment concludes that it is necessary and desirable to amend the Uniform Partnership Act in order to implement the proposed compensation allowance.

\section{I}

\section{PARTNERSHIP DisSOLUTION UNDER THE CURRENT REgIME}

This Part sketches the contours of the legal framework within which disputes arising out of the dissolution of law partnerships currently are resolved. There are some very basic policy threads that bind together the statutory weave. First, a partnership is prinarily a inatter of contract. Thus, partners will not be held to duties to which they did not explicitly or by clear implication agree to be bound. Second, partners are fiduciaries. When dealing with the partnership, therefore, a partner must exercise the utmost good faith. Finally, in the context of a law partnership, dissolution may not only affect the relations among partners, but may have severe repercussions on the relations between attorney and client. An ideal systein of rules for the dissolution of law partnerships, therefore, must account for each of these considerations.

\section{A. The Basic Framework}

A partnership can be one of two kinds-"at will" or "for a term." When a partnership is at will, eacli partner has both the power and the 
right to dissolve the partnership at any time. ${ }^{14}$ In a partnership for a term, the partners have agreed to remain together for a certain duration of time or to accomplish a specific undertaking. ${ }^{15}$ A partnership for a term can also be dissolved by the express will of any partner, but the dissolution will be deemed "in contravention of the agreement." 16 In such an event, the dissolving partner will be hable to his or her remaining partners for damages resulting from the wrongful dissolution. ${ }^{17}$ Thus, in a partnership for a term, eacli partner has the power but not the right to dissolve at any time. ${ }^{18}$

As between the two types of partnerships, a partnership at will is more prominent. The Uniform Partnership Act inakes it clear that the law favors free mobility of labor and capital by providing that a partnership inay be dissolved by the express will of any partner, regardless of whether it is in contravention of the agreement. ${ }^{19}$ Dissolution is not in contravention of the agreement in the absence of a particular term or specific undertaking. Thus, under the Act, partners are not held to a term unless they have clearly manifested such an intention. To this end, the Act places tlie burden of proving that a partnership was for a term on the partner making such an assertion.

Writing for the Califorma Supreme Court in Page v. Page, ${ }^{20}$ Justice Traynor einphasized the statutory preference for at-will partnerships, holding that absent a clear intent to the contrary, a partnership for a term will not be implied. ${ }^{21}$ In Page, a partner in a linen supply business sought damages from his dissolving partner, arguing that there was an

14. The Uniform Partnership Act provides that "[d]issolution is caused . . . without violation of the agreenient between the partners. . . [b]y the express will of any partner when no definite term or particular undertaking is specified." UNIF. PARTNERSHIP ACT § 31(1)(b), 6 U.L.A. 376 (1969); CAL. CORP. CODE § 15031(1)(b) (West 1977); see also supra note 7.

15. See supra note 14; see also Bates v. McTammany, 10 Cal. 2d 697, 76 P.2d 513 (1938) (finding partnership was one formed for a definite undertaking).

16. The Uniform Partnership Act provides that "[d]issolution is caused . . . [i]n contravention of the agreement between the partners, where the circumstances do not permit a dissolution under any other provision of this seetion, by the express will of any partner at any time." UNIF. PARTNERSHiP ACT § 31(2), 6 U.L.A. 376 (1969); CAL. CORP. CODE § 15031(2) (West 1977).

17. "Each partner who has not caused dissolution wrongfully shall have ... [t] against each partner who has caused the dissolution wrongfully, to damages for breach of the agreement." UnIF. PArTnership ACT § 38(2)(a)(II), 6 U.L.A. 456 (1969); Cal. CORP. CODE $\S 15038(2)(\mathrm{a})(\mathrm{II})$ (West 1977); see also supra note 7.

18. See, e.g., Straus v. Straus, 254 Minn. 234, 244, 94 N.w.2d 679, 686 (1959) (distinguishing between the power and the right to dissolve); A. BROMBERG, supra note 1, §§ 74(b), 75(a) at 422-23, 427-28; Hillnan, The Dissatisfied Participant in the Solvent Business Venture: $A$ Consideration of the Relative Permanence of Partnerships and Close Corporations, 67 MinN. L. Rev. 1, 8-35 (1982); see also supra note 7.

19. UnIF. Partnership Act $\S \S 31(1)(b)$ and 31(2), 6 U.L.A. 376 (1969); CAL. Corp. CODE $\S 15031$ (West 1977); see supra note 14.

20. 55 Cal. 2d 192, 359 P.2d 41, 10 Cal. Rptr. 643 (1961).

21. Id. at 196,359 P.2d at 43,10 Cal. Rptr. at 645 . 
implied understanding between the partners to continue the business until it paid for itself. The court commented that sucli an understanding "was no more than a common liope that tlie partnership earnings would pay for all the necesary expenses."22 According to the court, such hopes do not establish "even by implication"23 the "definite term or particular undertaking" 24 required by the statutory standard. The Page court tlius refused to imply a term even though the dissolution caused extrene hardship to the nondissolving partner. ${ }^{25}$

Partners are held, however, to mutual fiduciary duties whiclı may affect a partner's decision to dissolve the partnership. ${ }^{26}$ Thus, as the Page court noted in dictun, while "the Uniform Partnership Act provides that a partnership at will may be dissolved by the express will of any partner . . . this power, like any otler power held by a fiduciary, must be exercised in good faitli."27 As a fiduciary, a partner inay not dissolve for the purpose of taking unfair advantage of the partnership. Thus, a bad faith dissolution, like a wrongful dissolution, will lead to an action for damages by the reinaining partners. ${ }^{28}$

22. Id.

23. Id.

24. Id. (quoting UNIF. PARTnership ACT § 31(1)(b), 6 U.L.A. 376 (1969); CaL. CorP. CODE $\S 15031$ (West 1977); see supra note 14. As Professor Hillman has noted, see Hillman, supra note 18, at 19-27, earbier California courts demonstrated a much greater willingness to find implied terms or undertakings. See, e.g., Owen v. Cohen, 19 Cal. 2d 147, 119 P.2d 713 (1941) (terms of partnership to operate bowling alley were not expressly fixed, but agreement indicated parties intended relationship to continue until obligations were hquidated); Zeibak v. Nassar, 12 Cal. 2d 1, 82 P.2d 375 (1938) (implying that partnership formed to acquire a busmess whose pricipal assets were theater leases was formed for a term of similar duration as that of the leases).

However, even Professor Hillman recognizes that the decision in Page "is sone evidence that the inclination of the Califorma courts to imply ternis or undertakings has been suspended, if not terminated ... and thus nay undermine the earlier decisions [that readily implied terms or undertakings on "weak" facts]." Hillman, supra note 18, at 26-27 (emphasis added).

25. The defendant in Page alleged that he had invested substantial sums in the partnership, but that due to extended losses in the operation of the linen supply business, his interest in the partnership assets was small. He further alleged that because the plaintiffs wholly owned corporation held a large demand note of the partnership, it would be difficult to sell the linen busmess as a going concern. Thus, dissolution of the partnership would enable the dissolving partner to renove him at a small price even though the business had become very profitable due to the establishment of a military base in the vicimity. Page, $55 \mathrm{Cal} .2 \mathrm{~d}$ at 196, 359 P.2d at 44, $10 \mathrm{Cal}$. Rptr. at 646.

26. As stated by the court in Page:

Partners are trustees for each other, and in all proceedings connected with the conduct of the partnership every partner is bound to act in the highest good faith to his copartner and may not obtain any advantage over him in the partnership affairs by the slightest misrepresentation, concealment, threat or adverse pressure of any kind.

Id. at 197, 359 P.2d at 44, 10 Cal. Rptr. at 646 (quoting, inter alia, Llewelyn v. Levi, 157 Cal. 31, 37, 106 P. 219, 221 (1909)).

27. Id. at 196, 359 P.2d at 44, 10 Cal. Rptr. at 646.

28. As stated by the court in Page:

[P]laintiff has the power to dissolve the partnership by express notice to the defendant. If, however, it is proved that plaintiff acted in bad faith and violated his fiduciary duties by 
While bad faith is not a rigidly defined concept, in the context of a law-firm dissolution, it is likely to arise where a partner dissolves the partnership for the purpose of "grabbing"29 lucrative cases already being handled by the firm. A partner who dissolves in an effort to capture unfinished partnership business is vulnerable to a claim for breach of a fiduciary duty. ${ }^{30}$

\section{B. Law Firm Dissolution and Client Choice}

\section{The Client's Freedom of Choice}

In general, the law has favored allowing chents wide latitude in determining whether or not to discharge a particular attorney or group of attorneys. The general rule, simply stated, is that a chent has the

attempting to appropriate to his own use the new prosperity of the partnership without adequate compensation to his copartner, the dissolution would be wrongful and the plaintiff would be liable as provided by [the code sections dealing witl the rights of partners upon wrongful dissolution]. . . .

Id. at 197, 359 P.2d 45, 10 Cal. Rptr. at 647 (emphasis added). For a summary of the riglits of partners upon wrongful dissolution, see supra note 7.

Professor Hillman argues tliat while the Page court by refusing to imply a term absent such an intent by the parties sensibly gave effect to the U.P.A.'s policy that partnerships should be freely dissolvable, it nevertheless undermined that policy by equating a "bad faitll" dissolution with a "wrongful" dissolution. Hillman, supra note 18, at 27-33. He argues that the Page dictum may have the effect of "requiring retroactive analyses of the motives behind dissolutions . . . [thereby] creat[ing] the possibility of the terminable at will partnership whicl cannot be dissolved witl any degree of certainty concerning the consequences of that dissolution." Id. at 31 .

Regardless of the inerits of this particular aspect of Professor Hillman's argument, the compensation model proposed by this Comment would at least partially address Professor Hillman's concerns by placing the burden of proving bad faith on the partners asserting it. See infra notes 148-56 and accompanying text.

29. This Comment borrows the term "grabbing" frotn Professors Gilson and Mnookin, but we have modified the defimition as used here. Professors Gilson and Mnookin use the term to describe instances when a partner remains witlı a firm, bnt deinands inore tlian lis or her previously agreed share of firm profits as a condition for retnaining. They distimguisl the term "leaving," whicll they use to describe the situation where a partner leaves the firm and takes clients with lim or lier. Gilson \& Mnookin, supra note 3, at 6 . This Cominent uses the term "grabbing" to describe tlie situation Professors Gilson and Mnookin would describe as "leaving."

30. See, e.g., Leff v. Gunter, 33 Cal. 3d 508, 658 P.2d 740, 189 Cal. Rptr. 377 (1983) (competing with partnerslip during winding-up period held a breaclı of duty); Page v. Page, $55 \mathrm{Cal}$. 2d 192, 197, 359 P.2d 41, 44, 101 Cal. Rptr. 643, 646 (1961) ("A partner may not dissolve a partnership to gain the benefits of the business for himself, nnless lie fully compensates his copartner for lis share of the prospective business opportumity."); Rosenfeld, Meyer \& Susman v. Colıen, 146 Cal. App. 3d 200, 194 Cal. Rptr. 180 (1983) (partners may not dissolve law partnership in order to capture unfinisled business of the partnership). It is unclear whetler such an action would lie against a partner who dissolved inerely to capture the future business of a particular chent. See infra note 42. That question is obscured by two furtler complications. First, the distinction between "unfinisleed business," whicl belongs to the partnership; and "new business," whicl does not, is sometimes a difficult one to ascertain. Second, while the client is often consulted as to which attorney he or sle prefers to retain, the final division of the dissolving firm's business is determined by the court and the attorneys. 
absolute power to discharge an attorney, with or without cause. ${ }^{31}$

The rationale for this rule stems from the unique role that attorneys play im counseling chients. In litigation, the attorney is responsible for making tactical decisions both at the pretrial and trial stages. The client's role is usually limited to providing information and making the final decisions regarding settleinents. Indeed, decisions on tactics and day-today inanageinent of the case generally are made by the attorney. In nonlitigation situations, however, the chent may play a more active role in making tactical decisions. Nonetheless, without complete confidence in the attorney, the chient's decision to follow the attorney's instructions or to execute the prepared documents is impaired..$^{32}$

Recognizing the importance of chient choice, the California Supreme Court held in Fracasse v. Brent ${ }^{33}$ that a chent cannot be sued for breaching a contingent-fee contract with a law firm even when the firm lias financed the client's hitigation. The rule laid down in Fracasse allows only a quantuin meruit recovery against the chent, and then only upon the happening of the contingency. ${ }^{34}$ This special treatinent of clients stems from the concern that a client's right to discharge an attorney will be illusory "if the chent inust risk paying the full contract price for services not rendered upon a determination by a court that the discharge was without legal cause."35 In other words, the rule is designed to ensure that the client lias in practice the right to which it is indisputably entitled in theory.

\section{Law Firm Dissolution and the Concept of "Unfinished Business"}

The primciple of chent choice inay, however, conflict with tle fiduciary obligations of a partner as enunciated im Page. A partnership does not end upon dissolution, but continues during the winding up of partnership affairs. ${ }^{36}$ While the U1niform Partnership Act provides that each partner not wrongfully causing dissolution has a right to wind up the

31. See, e.g., Fracasse v. Brent, 6 Cal. 3d 784, 790, 494 P.2d 9, 13, 100 Cal. Rptr. 385, 389; see also Cal. Crv. Proc. Code $\S 284$ (West 1982).

32. Fracasse v. Brent, 6 Cal. 3d 784, 789, 494 P.2d 9, 12, 100 Cal. Rptr. 385, 388 (1972); see also Spiegel, Lawyering and Client Decisionmaking: Informed Consent and the Legal Profession, 128 U. PA. L. REv. 41 (1979) (outlining the importance of client decisionmaking in arguing for abandonment of the tactic/subject-matter distimction and for adoption of an informed consent standard).

33. 6 Cal. 3d 784, 494 P.2d 9, 100 Cal. Rptr. 385 (1972).

34. Id. at 792, 494 P.2d at 14, 100 Cal. Rptr. at 390. See generally Note, Limiting the Wrongfully Discharged Attorney's Recovery to Quantum Meruit-Fracasse v. Brent, 24 HASTINGS L.J. 771 (1973).

35. Fracasse, 6 Cal. 3d at 789, 494 P.2d at 12, 100 Cal. Rptr. at 388 (1972).

36. UNIF. PARTNERSHIP ACT $\S 30,6$ U.L.A. 367 (1969); CAL. CORP. CODE $\S 15030$ (West 1977); see supra note 8. 
partnership affairs, ${ }^{37}$ that right carries with it a duty. Each partner has a duty to complete all executory contracts for the benefit of the partnership as of the date of dissolution. ${ }^{38}$ The chent has the right to terminate a contract upon dissolution of a law partnership on the theory that the contract was one for the personal services of all the members of the firm. ${ }^{39}$ However, if the chent elects to have the contract completed, each partner is bound to comply. ${ }^{40}$

Because partners have a duty to complete the unfinished busmess of the dissolved partnership and may not dissolve for the purpose of grabbing that business, it is important to distimguish between unfinished business and new business. Courts have tended to define the unfinished business of a law firm as those cases already under contract on the date of dissolution, whether fee-based or contingent. ${ }^{41}$ On the other hand, additional services requested after dissolution by a former chent of the dissolved firm constitute "new" business. A partner who agrees to perform such services need not account to his or her former partners for any resulting fees. ${ }^{42}$

Because the fiduciary duty of partners to act in good faith extends throughout the winding-up period, ${ }^{43}$ the doctrine of unfinished business may operate to prevent grabbing of lucrative cases by dissolving partners. A partner who dissolves to capture the unfinished business of the partnership may well be hable for breach of fiduciary duty. ${ }^{44}$ Futhermore, a partner who causes a chient to discharge the partnership in order to appropriate the benefits of existing executory contracts after dissolution may be hable to his or her partners for tortious interference with contrac-

37. UNif. Partnership ACT § 37, 6 U.L.A. 444 (1969); CAL. Corp. Code $§ 15037$ (West 1977); see supra note 9.

38. See, e.g., Little v. Caldwell, 101 Cal. 553, 559-60, 36 P. 107, 108 (1894); Frates v. Nichols, 167 So. 2d 77, 80-81 (Fla. Dist. Ct. App. 1964); Platt v. Henderson, 227 Or. 212, 232, 361 P.2d 73, 82 (1961). See generally 60 AM. JUR. 2D Partnership § 247 (1972).

39. Little v. Caldwell, 101 Cal. 553, 559-60, 36 P. 107, 108 (1894); see also Wright v. McCampbell, 75 Tex. 644, 648, 13 S.W. 293, 295 (1890); see generally 60 AM. JUR. 2D Partnership $\S 247$ n. 16 (1972).

40. Little v. Caldwell, 101 Cal. 553, 559-60, 36 P. 107, 108 (1894); Felt v. Mitchell, 44 Ind. App. 96, 99, 88 N.E. 723, 723-24 (1909).

41. Smith v. Bull, 50 Cal. 2d 294, 304, 325 P.2d 463, 469 (1958); Rosenfeld, Meyer \& Susman v. Cohen, 146 Cal. App. 3d 200, 217, 194 Cal. Rptr. 180, 190 (1983); Heywood v. Sooy, 45 Cal. App. 2d 423, 426, 114 P.2d 361, 363 (1941).

42. Smith v. Bull, $50 \mathrm{Cal} .2 \mathrm{~d} 294,304,325$ P.2d 463, 469 (1958). Note, however, that this does not answer the question of whether a partner has breached a fiduciary duty when he or she dissolves for the sole purpose of capturing such new business. See supra text accompanying note 30 . The answer to that question might turn on the extent to which the dissolving partner solicited assurances from the client prior to dissolution. Cf. Rosenfeld, Meyer \& Susman v. Cohen, $146 \mathrm{Cal}$. App. 3d 200, 217-18, 194 Cal. Rptr. 180, 191-92 (1983).

43. See Leff v. Gunter, 33 Cal. 3d 508, 514, 658 P.2d 740, 744, 189 Cal. Rptr. 377, 381 (1983).

44. See supra note 30 and accompanying text. 
tual relations. ${ }^{45}$

The resolution of a discharge/rehire situation can be illustrated with a simple hypothetical. Assume that a client hires a law firm to represent it on a claim up to and mcluding trial. Assume further that one year before trial the partner primarily responsible for liandling the case dissolves the law firm in good faith and goes into practice alone. The client, wishing to retain the attorney familiar witl the case, independently discharges the old firm and negotiates with the dissolving partner a new contract calling for representation until termination of the litigation. Eventually the case goes to trial, the client recovers a substantial sum, and the defendant appeals. On appeal, the judgment is affirmed and the contractual arrangement ends. Clearly, the fees earned up to and including trial were fees covered by the original contract. Since the dissolving partner is under a duty to complete unfinished business for the benefit of the partnership, the new contract, insofar as it relates to these fees, nnay be considered a nullity without consideration. ${ }^{46}$ The dissolving partner may be deemed to loold these fees in constructive trust for the benefit of the partnership. ${ }^{47}$ However, fees generated by the appeal were not exphicitly covered by the origmal contract and thus may be considered new busmess for which the dissolving partner need not account. Consequently, while the client is free to clioose among attorneys or groups of attorneys, the chent's choice does not necessarily bear on the division of fees among the partners in a dissolved firm.

The extent to whicl the client's choice has actual value, however, may well depend upon how fees are divided among the partners in a law firm. The unfinished business doctrine undoubtedly promotes fiduciary responsibility by discouraging grabbing. Nevertheless, when coupled with the no-compensation rule, the doctrine may generate spillover effects that render illusory notions of at-will partners and client choice. The remainder of this Section explores the rationale of the no-compensation rule and examines the courts' strict adherence to the rule in the context of law partnership dissolutions.

\section{The "No-Compensation" Rule and Law Partnerships a. The Rationale of the No-Compensation Rule}

Partners must account to the partnership for all fees collected from the completion of unfinished busmess during the winding-up period. While partners may be able to deduct their expenses in generating those

45. Rosenfeld, Meyer \& Susman v. Cohen, 146 Cal. App. 3d 200, 220-27, 194 Cal. Rptr. 180, 192-97 (1983).

46. See, e.g., Frates v. Nichols, 167 So. 2d 77, 80 (Fla. Dist. Ct. App. 1964).

47. Rosenfeld, Meyer \& Susman v. Cohen, 146 Cal. App. 3d 200, 216-18, 194 Cal. Rptr. 180, 190-92 (1983). 
fees, ${ }^{48}$ they ordinarily are not entitled to retain any portion of the fees as "coinpensation" for their services in winding up the business after dissolution. ${ }^{49}$ Instead, the partners are required to divide the total fees collected according to their partnership interests or fee-splitting agreeinent. ${ }^{\text {so }}$

The rationale for the rule lies in the distinction between a partner and an employee. Partners are owners of the business, not employees. Consequently, they are not entitled to coinpensation for their services, but only to their share of the net profits of the partnership. ${ }^{51}$ A partner's compensation for services thus is limited to the "agreed rate" contained in the partnership contract. ${ }^{52}$ Furthermore, the duty of all partners to wind up the partnership affairs should ensure that the burden of completing unfinished business is distributed equitably. ${ }^{53}$ If, in fact, there is an inequitable distribution of winding-up burdens, partners should not be heard to complain because, in theory, this was a risk they undertook when becoining partners. ${ }^{54}$ Finally, partners who do not wish to assume such risks can guard against the contingency by entering into partnership dissolution agreeinents that provide for compensation in the event winding-up burdens fall disproportionately. ${ }^{55}$

The Uniform Partnership Act carries forth the common law nocoinpensation rule ${ }^{56}$ with one exception. It provides that "No partner is entitled to reinuneration for acting in the partnership business, except that a surviving partner is entitled to reasonable compensation for his services in winding up the partnership affairs." ${ }^{\text {.57 }}$ The rationale for the

48. Compare Jewel v. Boxer, 156 Cal. App. 3d 171, 180-81, 203 Cal. Rptr. 13, 19-20 (1984) (allowing deduction of overhead expenses attributable to winding up) with Hawkesworth v. Ponzoli, 388 So. 2d 299, 301 (Fla. Dist. Ct. App. 1980) (disallowing such deductions on the ground that such reinburseinent would amount to coinpensation).

49. Osment v. McElrath, 68 Cal. 466, 9 P. 731 (1886); Jewel v. Boxer, 156 Cal. App. 3d 171, 203 Cal. Rptr. 13 (1984); Frates v. Nichols, 167 So. $2 d 77$ (Fla. Dist. Ct. App. 1964); Resnick v. Kaplan, 49 Md. App. 499, 434 A.2d 582 (1981); Platt v. Henderson, 227 Or. 212, 361 P.2d 73 (1961); see also supra note 9.

50. Jewel v. Boxer, 156 Cal. App. 3d 171, 180, 203 Cal. Rptr. 13, 16 (1984); Frates v. Nichols, 167 So. 2d 77, 82 (Fla. Dist. Ct. App. 1964); Resmick v. Kaplan, 49 Md. App. 499, 506, 434 A.2d 582,587 (1981).

51. Unif. Partnership ACt $\S 18(a), 6$ U.L.A. 213 (1969); Cal. Corp. Code $\S 15018(a)$ (West 1966).

52. See supra note $\mathbf{5 0}$ and accompanying text.

53. See, e.g., Jewel v. Boxer, 156 Cal. App. 3d 171, 179, 203 Cal. Rptr. 13, 19 (1984).

54. See, e.g., Jacobson v. Wikholm, 29 Cal. $2 d$ 24, 28, 172 P.2d 878, 880 (1946) (explaining as the rationale of the common law no-compensation rule that the winding-up burden incident to the death of a partner was "one of the ordinary risks which a partner took").

55. Jewel v. Boxer, 156 Cal. App. 3d 171, 179-80, 203 Cal. Rptr. 13, 19 (1984).

56. See, e.g., Denver v. Roane, 99 U.S. 355 (1878) (under federal common law rule, no compensation even to surviving partners).

57. Un1F. Partnership ACT $\S 18(f), 6$ U.L.A. 213 (1969); CaL. Corp. Code $\S 15018(f)$ (West 1977). 
exception is that while all partners have a duty to wind up the affairs of the dissolved partnership, that burden will fall entirely upon the surviving partners when dissolution is caused by the death of a partner. ${ }^{58}$ In such a case, it is equitable to allow the surviving partner or partners to deduct coinpensation as against the partnership share of the deceased partner. This exception deinonstrates that the legislature recognized, at least in one area, the inequity of allowing the burden of winding up at dissolution to fall disproportionately on an individual.

\section{b. Compensation in the Law Partnership Context}

While several courts ${ }^{59}$ and at least one commentator ${ }^{60}$ have suggested that the rationale of the no-coinpensation rule fails in the context of service partnerships, most courts have read the explicit provision in the Uinform Partnership Act to preclude coinpensation to all but surviving partners. ${ }^{61}$ They have resisted efforts to expand the definition of a "surviving partner," 62 and have deinonstrated an unwillingness to carve out further exceptions on equitable grounds. ${ }^{63}$ These courts have rejected the suggestion that professional partnerships should be treated differently from ordinary commercial partnerships, noting that the Uniform Partnership Act defines "business" as "every trade, occupation, or profession." 64 Thus, for example, in Frates $v$. Nichols ${ }^{65}$ a Florida court rejected the notion that upon dissolution a firm's retamer agreenents expire, thereby enabling a dissolving partner to substitute new retainer agreements with the former client and to keep all fees except a quantuin meruit payinent to the old firm for predissolution services. ${ }^{66}$ The court uncritically apphed the proposition that a law partner is duty-bound to wind up pending business upon dissolution and is entitled to no extra coinpensation for doing so. ${ }^{67}$ Reinaining faithful to the concept of "unfinished busmess," the court noted that inasmuch as a dissolving partner is under a duty to wimd up, the signing of a retainer agreement

58. See Jacobson v. Wikholm, 29 Cal. 2d 24, 28, 172 P.2d 878, 880 (1946); Griggs v. Clark, 23 Cal. 427, 431 (1863); Chazan v. Most, 209 Cal. App. 2d 519, 523, 25 Cal. Rptr. 864, 866 (1962). See also UNIF. PARTNership ACT § 31(4), 6 U.L.A. 376 (1969); CAL. CorP. Code § 15031(4) (West 1977) (providing that dissolution is caused by the death of any partner).

59. See cases cited infra note 92.

60. Crum, supra note 4, at 284-91.

61. See, eg., Chazan v. Most, 209 Cal. App. 2d 519, 523-24, 25 Cal. Rptr. 864, 867 (1962).

62. Id. at 523, $25 \mathrm{Cal}$. Rptr. at 867 ("There is no merit in Most's contention that he is a 'surviving partner'.").

63. See, eg., Jewel v. Boxer, 156 Cal. App. 3d 171, 203 Cal. Rptr. 13 (1984).

64. Unif. Partnership ACT $\S 2,6$ U.L.A. 12 (1916); Cal. CorP. Code $\S 15002$ (West 1966) (emphasis added); see also Jewel v. Boxer, 156 Cal. App. 3d 171, 177, 156 Cal. Rptr. 13, 16-17 (1984); Resmick v. Kaplan, 49 Md. App. 499, 509, 434 A.2d 582, 588 (1981).

65. 167 So. 2d 77 (Fla. Dist. Ct. App. 1964).

66. Id. at 80 .

67. Id. 
with an existing chent is void as lacking consideration. ${ }^{68}$

Similarly, a recent line of California cases ${ }^{69}$ explicitly rejected the contention that compensation should be allowed to dissolvimg law partners. Tlius, for example, in Jewel v. Boxer, ${ }^{70}$ the court of appeal rejected the notion that law partners should be entitled to compensation for efforts expended in completing cases after dissolution. It held that fees received froin unfinislied business should be divided in accordance witl the partnership agreement. ${ }^{71}$ The court construed the language of the Unifornu Partnership Act as "unequivocally prohibiting" postdissolution compensation except in the case of a surviving partner. ${ }^{72}$ Furthermore, the court rejected the arguinent that by agreeing to a substitution of attorneys the client transforned the dissolved firm's unfinislied busmess into new business of the dissolving partners, thereby rendering the relevant sections of the Act inapplicable. ${ }^{73}$ The court fully agreed that a chent has a right to attorneys of its choice, but reasoned that once the client pays its fee, the division of that fee between the attorney and his or lier former partners is of no concern to the chient. ${ }^{74}$

While earlier cases had simply denied compensation by mechanically invoking the rule that a winding-up partner is entitled to no compensation, ${ }^{75}$ the Jewel court attempted to justify the application of the rule to law partnerships. Apparently concerned with the potential for grabbing, the court suggested that the rule "prevents partners from competing for the most remunerative cases during the life of the partnership in anticipation that they might retain those cases should the partnership dissolve."76 On the same note, the court indicated that the rule "discourages foriner partners from scrambling to take physical possession of files and seeking personal gain by solicitimg a firm's existing clients upon dissolution." "77 Rejectmg an argument that the rule discourages attorneys from representing former chents after dissolution by depriving them of the full fee, the court intimated that the respective attorney's partnership interest in the fee is all the attorney would had received had the firm not been dissolved. ${ }^{78}$ The court pointed out that such a partner is also enti-

68. Id.

69. Fox v. Abrams, 163 Cal. App. 3d 610, 617, 210 Cal. Rptr. 260, 266 (1985); Jewel v. Boxer, 156 Cal. App. 3d 171, 176-77, 203 Cal. Rptr. 13, 17 (1984); Rosenfeld, Meyer \& Susman v. Cohen, 146 Cal. App. 3d 200, 216-20, 194 Cal. Rptr. 180, 192 (1983).

70. 156 Cal. App. 3d 171, 203 Cal. Rptr. 13 (1984).

71. Id. at 176-77, 203 Cal. Rptr. at 16-17.

72. Id.

73. Id. at 178,203 Cal. Rptr. at 18.

74. Id. at 178, 203 Cal. Rptr. at 17.

75. See, e.g., Chazan v. Most, 209 Cal. App. 2d 519, 523-24, 25 Cal. Rptr. 864, 867 (1962).

76. Jewel, 156 Cal. App. 3d at 179, 203 Cal. Rptr. at 18.

77. $I d$.

78. Id. 
tled to his or her partnership interest in fees generated by the other partners in winding up. ${ }^{79}$ In this context, the court noted that because all partners are under a duty to wind up, their mutual fiduciary duties should ensure that the burdens of coinpleting unfinished business are not shifted disproportionately upon one or nore partners. ${ }^{80}$ Finally, the court noted that partners are free to provide for the payment of coinpensation in their partnership agreement in order to avoid frictions resulting froin inequitable distribution of work following dissolution. ${ }^{81}$ Thus, the court concluded that all postdissolution fees received from unfinished business inust be divided according to the partnership agreeinent, except that the partners should be entitled to reimbursement for reasonable and necessary overhead expenses attributable to the winding-up process.

Underlying the decision in Jewel is a reaffirmance of the fiduciary primciples announced in Page. The Jewel court attempted to legitinize the no-coinpensation rule in the context of law firm dissolutions by grounding the rule on well-established policies aimed at discouraging grabbing and at remforcing the fiduciary duty of partners to complete unfinished business. The Jewel court also recognized the special treatinent afforded to chent choice. Nonetheless, the court felt comfortable that the no-coinpensation rule and the concept of client choice did not "offend one another." 82 The next Part takes issue with that determination and suggests that the Jewel court also failed to account for the law's preference for at-will partnerships.

II

The Problem of Lock-IN ANd Lock-out

Because a law partnership renders personalized services, it is probable that winding-up burdens will fall disproportionately on the partners upon dissolution. This potential for inequity may alone warrant reexamination of the no-compensation rule as apphed to law partnerships. Supporters of the current regime, however, are likely to point out that partnership is a matter of contract, and as such, the law should hesitate to remake the parties' bargain. ${ }^{83}$ Furthermore, supporters are likely to assert that the current regime enforces the goal of ensuring fiduciary deahing between partners. ${ }^{84}$ Thus while the possible inequities generated by the rule are unfortunate, they would not justify the involveinent of scarce judicial resources. Rather than becoming involved in a time-con-

\footnotetext{
79. Id.

80. Id. at 179, 203 Cal. Rptr. at 19.

81. Id. at 179-80, $203 \mathrm{Cal}$. Rptr. at 19.

82. Id. at 177-78, $203 \mathrm{Cal}$. Rptr. at 17.

83. See, e.g., id. at 179-80, 203 Cal. Rptr. 13, 19 (1984).

84. Id. at 179, 203 Cal. Rptr. at 18.
} 
suming determination of which partner is entitled to what, supporters of the current regime argue that courts should allow the parties to taste the bitter and the sweet of their own contractual appetites.

This Part, however, suggests that in the context of a law partnership dissolution the inequities lurking beneath the shadows of the no-compensation rule generate further coinphications worthy of judicial resolutionthe phenomena of lock-in and lock-out. The workings of these evasive effects can be exposed through the use of a simplified hypothetical. First, however, it is helpful to note soine characteristic differences between law partnerships and other, inore general partnerships.

\section{A. The Unique Nature of Law Partnerships}

\section{Service Partnerships and General Partnerships}

The Uniform Partnership Act apphes both to general partnerships and service partnerships. These two forms of business, however, differ significantly. General partnerships typically produce products through the cumulative effort of the various partners and einployees. While there is an infinite variety of ways in which such a business can be organized, this type of partnership generally sells "impersonal" products, rather than products generated by an individual partner's lone efforts. As such, the assets of a general partnership upon dissolution often consist of saleable or assignable contracts. Winding up, therefore, often entails substitute performance of the contracts rather than completion by the partnership itself.

Service partnerships, on the other hand, generally are organizations whose products are produced by the partners individually. Partners inay associate to share expenses, to share risks, or to collaborate, ${ }^{85}$ but the primary output is the work of the individual partners. Therefore, the nature of the business is highly personal and depends on the skill of a particular partner and his or her relationship to the client. Consequently, upon dissolution, the assets of the firm in the form of unfinished business generally cannot simply be sold or assigned. The chents contracted for the work of specific individuals. At least in the context of law firms, attorneys are not permitted either to withdraw thenuselves and reassign the case to a different firm ${ }^{86}$ or to finish the work themselves for their own benefit after paying the old firm for its share of the work, ${ }^{87}$ and

85. See, e.g., Gilson \& Mnookin, supra note 3, at 8-18.

86. However, Model Rules of Professional Conduct Rule 1.16(b)(5) (1983) does allow withdrawal for "unreasonable financial burdens." Even then, the attorney must get the client's consent before assigning the case to a different lawyer. There is no corresponding provision in the Code of Professional Responsibility.

87. See, e.g., Little v. Caldwell, 101 Cal. 553, 559-60, 36 P. 107, 108 (1894). 
they certainly cannot sell the contract to another attorney. ${ }^{88}$ Thus, the winding-up burdens of the various partners within a law firm may well depend upon the fortuitous distribution of work annong the partners on the date of dissolution.

Recognition of these differences between service partnerships and general partnerships is not a recent phenomenon. As early as last century, the Supreme Court in Denver v. Roane ${ }^{89}$ noted by way of dictuin that these differences might justify liberalization of the no-compensation rule as applied to partners who must bear inequitable burdens in winding up service partnerships. ${ }^{90}$ Over the years, several courts relied on the dictum in Denver to allow coinpensation to law partners who expended a disproportionate effort in winding up the affairs of dissolved law firms. ${ }^{91}$ Most such reported decisions, however, predate the adoption of the

88. It is patently unethical for one lawyer to pay another lawyer for a referral of business. See Code of PRofessional ResponsibiltTy DR 2-103(B) (1980) and MODEL Rules of Professional Conduct Rule 7.2(b) (1983). Of course an attorney may pay the dissolving firm its proper share of the fees earned, see CODE OF PROFESSIONAL RESPONSIBILITY DR 2-107 (1980) and Model Rules of Professional Conduct Rule 1.5 (1983), but this does not include any premium value for the referral. Thus, the value of the remainder of the contract must go unrealized if the members of the dissolving firm do not themselves complete it.

89. 99 U.S. 355 (1878).

90. The Court stated that:

This [the no-compensation rule] is the rule in regard to what are coinmonly called commercial partnerships, and the authorities cited refer to those. There may possibly bc soine reason for applying a different rule to cases of winding up partnerships between lawyers and other professional men, where the profits of the firm are the result solcly of professional skill and labor.

Id. at 359. This decision was made under the "general common law" of Swift v. Tyson, 41 U.S. 1 (Pet. 1842).

91. Thus, in Lamb v. Wilson, 3 Neb. (Unof.) 496, 92 N.W. 167 (1902), rev'd on reh'g on other grounds, 3 Neb. (Unof.) 505, 97 N.W. 325 (1903), a Nebraska court noted the general rule against compensation, but allowed compensation anyway to the dissolving partners of a law firm, explaining:

[T] he rule [against compensation] should not be extended beyond the requirement of merely winding up the partnership affairs by collecting its outstanding claims, paying debts and distributing the surplus among the members, and that when it appears that time, skill and labor have been expended by a partner in the contmuance of tlic partnership business, which inures to the general benefit, he ought to receive from the profits from his skill and labor, a reasonable compensation, varying according to the nature of the business, the difficulties and results of the undertaking and its necessity or desirability. While few cases are found which directly support this view, it seems to us to be founded upon the plainest principles of equity and justice, especially when applied to partnerships annong professional men where the profits are almost wholly the result of professional skill and labor.

$3 \mathrm{Neb}$. (Unof.) at 496, $92 \mathrm{~N}$.W. at 168 . Thus, the court allowed the fees received to be divided pro rata between the dissolved firm and the dissolving partners in accordance with the value of the services each had contributed to the completion of the cases. This case, however, was decided by three commissioners and approved by the Nebraska Supreme Court only as to result, not as to rcasoning. However, the coinmissioners did sit as an appellate tribunal over a trial court. This opinion was later reversed on rehearing on other grounds. Although the headnote in the Nebraska unofficial reporter claims that the rehearing reversed the case on this point, that conelusion is not supported by the opinion itself, which merely noted that in the particular case the partners made a specific agreement contrary to the general rule. Lamb, 3 Neb. (Unof.) 505, 506-07, 97 N.W. 325, 326 (1903). 
Uniform Partnership Act in the respective court's jurisdiction. ${ }^{92}$ As noted earlier, tlie inajority of courts considering the matter after adoption of the Act have held that compensation is unavailable regardless of the inequalities of winding-up burdens, except in the narrow case of a surviving partner. ${ }^{93}$

Some courts, however, liave refused to follow tlie language of the Uniform Partnership Act and have allowed compensation to a law partner for winding up unfinished business after dissolution. In Cofer $v$. Hearne,${ }^{94}$ for example, the Texas Court of Civil Appeals stated that "we cannot bring ourselves to the voluntary acceptance of a rule which in our opinion, is unconscionable and inequitable." 95 The court lield that the portion of the disputed fee earned prior to dissolution should be divided according to partnership interests, and the portion earned after dissolution should be subject to the sole disposition of the winding-up partner. ${ }^{96}$ In effect, the court did away with the concept of "unfinished business" by treating the date of dissolution as denarcating the division between partnership business and separate business of the individual partners. ${ }^{97}$

\section{Law Partnerships Specifically}

The differences between a general partnership and a service partnership appear starker in the context of a law firm. There are two inajor

92. See, e.g., Jones v. Marshall, 24 Idaho 678, 680, 135 P. 841, 842 (1913) (Idaho adopted the Uniform Partnership Act in 1919); Lamb v. Wilson, 3 Neb. (Unof.) 496, 92 N.W. 167 (1902), rev'd on reh'g on other grounds, 3 Neb. (Unof.) 505, 97 N.W. 325 (1903) (Nebraska adopted the Uniform Partnership Act in 1943); Cunningham v. Madden, 115 W. Va. 286, 175 S.E. 446 (1934) (West Virginia adopted the Uniform Partnership Act in 1953). In Jones and in Cunningham, the partners performing the winding-up services were surviving partners. Thus, those decisions may reflect only the courts' concerns with the harshness of the common law no-coinpensation rule rather than any serious atteinpt to differentiate between service partnerships and ordinary commercial ones. Today, those deeisions would be justified by UNIF. PARTNERShIP ACT § 18(f), 6 U.L.A. 213 (1969); CAL. CORP. CODE $\S 15018(f)$ (West 1977); see supra note 9. However, soine jurisdictions have allowed coinpensation even after the adoption of the U.P.A. See In re Mondale, 150 Mont. 534, 542-43, 437 P.2d 636, 641 (1968) (Montana adopted the Uniform Partnership Act in 1947); Cofer v. Hearne, 459 S.W.2d 877, 879 (Tex. Civ. App. 1970) (Texas adopted the Uniform Partnership Act in 1961).

93. See, e.g., Jewel v. Boxer, 156 Cal. App. 3d 171, 180, 203 Cal. Rptr. 13, 19 (1984); Rosenfeld, Meyer \& Susman v. Cohen, 146 Cal. App. 3d 200, 194 Cal. Rptr. 180 (1983); Frates v. Nichols, 167 So.2d 77, 80 (Fla. Dist Ct. App. 1964); Resnick v. Kaplan, 434 A.2d 582, 587 (1981); Platt v. Henderson, 227 Or. 212, 234, 361 P.2d 73, 83 (1961).

94. 459 S.W.2d 877 (Tex. Civ. App. 1970).

95. Id. at 880. Note that the court in Cofer refused to follow an earlier Texas Court of Civil Appeals decision to the contrary in Phoenix Land Co. v. Exall, 159 S.W. 474 (Tex. Civ. App. 1913). Thus, two different courts of appeals have coine to opposite conclusions within the same jurisdiction. The controversy has not yet been resolved by the Texas Supreine Court. See Crum, supra note 5, at 288.

96. Cofer, 459 S.W.2d at 881 .

97. In remanding the case for a determination of the fee-division issue, the court suggested that while the amount of tinie spent on a case before and after dissolution is a relevant factor, it is only "evidentiary," not conclusive. Id. at 885 . 
concerns in this area. The first stems from the nature of the attorneyclient relationship. The second involves the inability of law firms to fully incorporate.

The practice of law is umque in that the relationship between the attorney and the chent is paramount. Utterances between thein are exempt from even compelled disclosure. ${ }^{98}$ All other information received by the attorney relating to the client, subject to a few exceptions, can be disclosed only by legal compulsion. ${ }^{99}$ Thus, the client is encouraged to put coinplete trust in the attorney. Further, the special expertise of the lawyer puts him or her in an influential position as advisor to the client. ${ }^{100}$

Despite this position of reliance, clients often are unable to guage in advance whether the relationship will prove satisfactory. Due to the personal nature of an attorney's services, especially in the counseling context, even information regarding the lawyer's reputation may not enable the client to predict the outcome of the relationship. Recognizing this limitation, the law allows a client to terminate a particular attorney-client relationship at any time, with or without cause. Nevertheless, absent client agreement to the contrary, the client agrees otherwise, law partners are bound to complete executory contracts with clients even upon dissolution of the law firm. ${ }^{101}$ Of course, when a law firm dissolves, clients will rarely see lawyers as fungible. Consequently, to effectuate the goal of client choice, law partners inay sometines be required to assume inequitably distributed winding-up burdens.

Of course, the partners can agree by contract to provide for compensation in the event winding-up burdens fall inequitably. Nevertheless, because partnerships are likely to be forged in an atmosphere of optimism and mutual respect, partners may suppress notions of dissolution and conflict. Should the various partners consider the potential problems involved in dissolving, they anay choose not to raise the issue for fear of disrupting the harmony of the moment.

In the context of ordinary commercial businesses, these potential frictions can be largely avoided through incorporation. Once incorporated, owners can hire themselves as employees of the corporation. As such, they are entitled to compensation. If compensation is determined

98. See Cal. Evid. Code $\S 955$ (West 1966).

99. See Code of Professional Responsibility DR 4-101 (1980) and MOdel Rules of Professional Conduct Rule 1.6 (1983).

100. Many clients are not sophisticated in legal matters and look to the lawyer as an unquestioned source of legal information and advice. Whether rightly or wrongly, many, if not most attorneys encourage this type of relationship. See D. ROSENTHAL, LAWYERS AND CLIENTS: WHO'S IN CHARGE, 13-16 (1974).

101. But see Model RUles of Professional Conduct Rule 1.16(b)(5) (1983) (allowing withdrawal by the attorney for "unreasonable financial hardship"). 
by the unit of time worked, then the problem of inequitable distribution of burdens is resolved.

California, however, severely restricts the ability of attorneys to incorporate. In addition to the traditional ethical rules regarding incorporating with nonlawyers, ${ }^{102}$ a recent California case has determined that a law corporation is to be treated as a partnership for all but tax purposes, specifically for purposes of winding-up. In Fox $v$. Abrams, ${ }^{103}$ the court of appeal held that, despite the corporate forn of the law firm, the policies behind Jewel dictate that the division of momes after dissolution be governed by the no-compensation rule. ${ }^{104}$ The court noted that "[i]t is well-known that the primary purpose of the laws permitting professionals to incorporate was to allow them to take advantage of various tax benefits available to corporate employers and employees." 105 The court held, therefore, that the work in process at the time of the corporate dissolution was to be considered unfinished business and the fees were to be divided according to the Jewel no-compensation rule. ${ }^{106}$ The court's ruling seemed to be based on a policy of preventing grabbing and promoting fiduciary responsibility among the partners. Attorneys in California, therefore, cannot avoid the no-coinpensation rule by incorporating. Unless the partners explicitly provide for compensation in the partnership agreement, the no-compensation rule will be applied to winding-up law partners regardless of the mequities involved. These inequitable burdens of winding up may lead to more significant concerns of lock-in and lock-out. The potential for lock-in and lock-out may be illustrated by a simple hypothetical.

\section{B. Lock-in and Lock-out: A Simplified Hypothetical}

Alvin, Birney, and Chandler have been partners in a relatively successful law firn for many years. Alvin and Birney generally handle a high volume of tort cases, no one of which takes any significant amount of time to complete. Chandler, though, has been working full-time on a multiparty multidistrict class action suit. The partnership accepted the class action suit on a contingent fee basis and calculated that the case would take up to five years to try or settle. Thus, while the case has not yet generated any fees, the partnership expects to receive one-third of any eventual recovery.

This division of work generally has been acceptable to all parties.

102. See Code of Professional Responsibility DR 3-103, 5-107(c) (1980) and Model Rules of Professional Conduct Rule 5.4 (1983).

103. 163 Cal. App. 3d 610, 210 Cal. Rptr. 260 (1985).

104. Id. at $615-16,210 \mathrm{Cal}$. Rptr. at 265 .

105. Id. at 616-17, 210 Cal. Rptr. at 265.

106. Id. at $617,210 \mathrm{Cal}$. Rptr. at 266 . 
Three years after the commencement of her class action suit, however, Chandler dissolves the firm in good faith and goes into practice on her own. Alvin and Birney decide to remain together as a new partnership.

Six months after dissolution of the partnership, Alvin and Birney complete all of their unfinished partnership business, bringing in a total of $\$ 300,000$ in fees. Over the next year and a half, they earn $\$ 1,200,000$ working on new business assumed after the dissolution. During the same two-year period following dissolution, Chandler works full-time on the class action suit. At the end of the two-year period, she settles the case for $\$ 9,000,000$, thus bringing in $\$ 3,000,000 \mathrm{~m}$ fees under the contingentfee contract.

Under current law, resolution of the hypothetical leads to inequitable results. While theoretically each partner is under a duty to wind up the unfimished busimess of the partnership, equal division of the work is impossible because the unfimished business consists of a number of small cases and one very large case. Thus, Alvin and Birney each complete only one-sixth of the unfinished business while Chandler is forced to assume two-thirds of the winding-up burden. Nevertheless, the $\$ 3,300,000$ in fees resulting froin unfinished partnership business ( $\$ 300,000$ froin Alvin and Birney, $\$ 3,000,000$ from Chandler) belongs to the partnership and each partner is entitled to draw his or her partnership share. Assuming for the sake of simplicity that each partner shares equally, Alvin and Birney are entitled to draw $\$ 2,200,000$ through a partnership accountimg and also inay retain the full $\$ 1,200,000$ in fees that they earned froin new busimess during the two-year period. Thus, Alvin and Birney each earn $\$ 1,700,000 \mathrm{im}$ fees for the two-year winding-up period. Chandler, on the other hand, reahzes only $\$ 1,100,000$ - substantially less than Alvim and Birney, though she performed four times as much work as either in winding up the partnership affairs.

Of course, this discrepancy arises because for a year and a half Alvin and Birney were working for their own benefit on new business, while Chandler was still working full time on the class action for the benefit of the partnership. Because the law distinguishes between new business and unfinished business, Chandler is not entitled to share in the fees generated by Alvin and Birney during that one and one-half year period. Thus, the concept of unfimished business, coupled with the no-compensation rule, can lead to wide disparities between the effort expended by a winding-up partner and the remuneration received for the fulfillment of that duty.

This disparity, in turn, can undennine the law's preference for at will partnerships ${ }^{107}$ by discouraging a partner from exercising his or her

107. See supra text accompanying notes 14-25. 
right to dissolve. Had Chandler considered the consequences of her action, she might well have decided against dissolution. This lock-in effect might have been exacerbated had Chandler considered the consequences of losing the class action suit. In that event, Chandler would have received only $\$ 100,000$ (one-third of the fees brought in by Alvin and Birney from unfinished busimess) for the two-year period she spent winding up the class action suit. Alvin and Birney, who carried their winding-up burdens for only six months, would receive $\$ 1,400,000$ $(\$ 200,000$ from unfinished business, $\$ 1,200,000$ from new busmess) over the same period. Thus, while Chandler im theory has the right to dissolve the partnership at will, the consequences of that dissolution may in practice render the "right" illusory. ${ }^{108}$ The problem becomes more disturbing if Alvin and Birney were the ones demanding dissolution. Under such circumstances, the no-compensation rule would not even serve to prevent grabbing. On the contrary, it might encourage partners to dissolve whenever their winding-up burdens would be light relative to those of their partners.

In theory, Chandler could have insisted that Alvim and Birney wind up the class action or at least contribute their services toward its completion. When the chient retained the firm, it retained the entire firm, not any particular attorney. ${ }^{109}$ All partners are under a duty to complete the unfinished busmess of the firm; ${ }^{110}$ thus any partner could complete the case without breaching the duty to the chent.

However, from the chient's perspective, a change of attorneys is inefficient. Chandler has handled the case for three years prior to dissolution. She may well have developed a familiarity with the case that cannot be replaced easily. In all likelihood, she has developed a.close relationship with the client. Clearly, the client would prefer to have Cliandler complete the case. Nevertlieless, the cost to Chandler imposed by the no-compensation rule may render her unable or unwilling to continue with the case. Furthermore, the client cannot lielp Cliandler avoid the consequences of the rule by discliarging the old firm, which still exists for the purposes of wimding üp, ${ }^{111}$ and retaining Cliandler under a new contract. To do so would make Cliandler liable in tort to the other partners for the full fees stated in the original contract. ${ }^{112}$ Thus, despite the

108. Professor Hillman has questioned whether or not the Page court's equation of a bad faith dissolution with a wrongful one might have the same effect. See supra note 28.

109. See, e.g., Little v. Caldwell, 101 Cal. 553, 559, 36 P. 107, 108 (1894); Wright v. McCampbell, 75 Tex. 644, 648, 13 S.W. 293, 295 (1890).

110. See, e.g., Jewel v. Boxer, 156 Cal. App. 3d 171, 179, 203 Cal. Rptr. 13, 19 (1984).

111. See supra notes $45-47$ and accompanying text; see also UNIF. PARTNERSHIP Acr $\S 30,6$ U.L.A. 367 (1969); CAL. CoRp. CODE $§ 15030$ (West 1966).

112. See, e.g., Rosenfeld, Meyer \& Susman v. Cohen, 146 Cal. App. 3d 200, 194 Cal. Rptr. 180 (1983). In that case, the client, Rectifier, discharged the old firm and hired the dissolving partners 
policies favoring client choice, the client may be locked-out of having the attorney of its choice. This lock-out effect of the no-compensation rule is not only undesirable from the chent's perspective, but is inefficient.

The discrepancy in fee-allocation caused by the no-compensation rule becomes exacerbated as the size of the firm and the disparity of work apportionment increase. The relevant variables become the time lag during which some, but not all, partners are working on new business, and the number of partners among whom the recovery must be shared.

Whether the current regime achieves the very policies it seeks to promote is questionable. According to Jewel, the no-compensation rule strengthens the fiduciary relationship between partners by discouraging grabbing ${ }^{113}$ and by encouraging an equitable distribution of winding-up burdens. Jewel also suggests that the no-compensation rule proinotes freedom of contract by refusing to provide for compensation where the parties have failed to do so. ${ }^{114}$ Finally, while Jewel recognizes the principle of chent choice, it assumes that the no-compensation rule is compatible with the attainment of that goal. ${ }^{115}$ This Part has argued that where the no-compensation rule promotes one aspect of freedom of contractby refusing to imply compensation-it destroys another by coercing partners to remain together when they contracted for a partnership at will. Furthermore, this Part has suggested that the brunt of the no-coinpensation rule may fall not upon the various partners, but upon the clientwho may be precluded from retaining the attorney of its choice.

The current regine's emphasis on proinoting fiduciary responsibility at all costs, therefore, may result in lock-in and lock-out. This Part has suggested that, iromically, the current regime may fail even to prevent grabbing. While the no-compensation rule discourages dissolution in order to grab lucrative cases, it may encourage partners to dissolve when their winding-up burdens are light compared to those of their partners. ${ }^{116}$ Furthermore, the no-compensation rule cannot promote equal distribution of winding-up burdens where those burdens are incapable of any sensible division. With relatively minor changes, however, the ten-

Cohen and Riorden. The court found that by accepting that case, Cohen and Riorden had breached their duty to complete unfinished business on behalf of the firm. They were held liable for the original contract. Id. at 218-20, 194 Cal. Rptr. at 191-92; see also Little v. Caldwell, 101 Cal. 553, 560, 36 P. 107, 108 (1894), Jewel v. Boxer, 156 Cal. App. 3d 171, 203 Cal. Rptr. 13 (1984).

113. Jewel v. Boxer, 156 Cal. App. 3d 171, 179, 203 Cal. Rptr. 13, 18 (1984).

114. Id. at 179-80, $203 \mathrm{Cal}$. Rptr. at 19.

115. Id. at 177-78, 203 Cal. Rptr. at 17.

116. Where a minority of partners is working on a large case over time, a dissolution will benefit the other partners who would be working on "new" business shortly after the dissolution. They would be able to retain $100 \%$ of the proceeds, while their colleagues working on "unfinished business" would be required to account to the partnership. This would occur if, for example, Alvin and Birney had decided to dissolve. Admittedly this is a somewhat rare occurrence, since the dissolving partners would thereby forfeit income from any future business with the particular client. 
sions in the law could be resolved equitably for both the partners and for the chent.

\section{III \\ REPLACING THE CURRENT REgIME}

This Comment has argued that it is the no-compensation rule coupled with the doctrine of unfinished business that leads to inequitable results whenever partners' winding-up burdens are unevenly distributed. This Comment further argued that those inequities, in turn, generate the phenomena of lock-im and lock-out, thereby undermining the policies favoring at-will partnerships and chent choice. An examination of the factors causing the mequities under the current regime suggests two possible ways to alleviate the problem. The first is to eliminate the doctrine of unfinished business. The second is to eliminate the no-compensation rule. Adopting the former approach, this Comment develops the separate business model, which proposes a complete severance of the partnership at the time of dissolution. This Comment further proposes the compensation inodel, which opts for the latter approach by allowing partners to draw compensation to the extent they bear a disproportionate burden in winding up the affairs of the dissolved partnership. Section $A$ defines these proposed alternatives. Section $B$ then analyzes and compares the models.

\section{A. The Proposed Alternatives}

\section{The Separate Business Model}

The crux of the separate business model hes in its complete rejection of the unfinished business doctrine. Accordingly, dissolution and termination become synonymous, and a partnership is deemed to terminate on the date of dissolution. Of course, the partners still owe a duty to the clients to complete executory contracts. ${ }^{117}$ Thus, upon dissolution partners take their cases (and perhaps their clients) with them and complete them to the satisfaction of the chent. Unlike under the current regime, however, all fees earned after the date of dissolution accrue to the sole benefit of the partner performing the work, not to the firm as a whole. Thus, the act of dissolution serves to transform partnership business into the separate business of the individual partners.

Calculating which fees accrued prior to dissolution and which accrued after is a simple matter where fees are determined on an hourly basis. Allocating fees received from cases carried on a contingent-fee basis is more difficult since fees are not collected until completion of the

117. Jewel v. Boxer, 156 Cal. App. 3d 171, 179, 203 Cal. Rptr. 13, 19 (1984). See also UN1F. PartnershiP ACT § 21, 6 U.L.A. 258 (1969); Cal. CorP. CODE $\$ 15021$ (West 1977). 
case. Even so, courts are generally experienced in allocating such recoveries based on the percentage of work done on the case before and after dissolution. ${ }^{118}$

Under this inodel, the old partnership is entitled to a quantum meruit recovery similar to that allowed by courts recognizing a client's right to discharge an attorney retained under a contingent-fee contract. ${ }^{119}$ The quantum meruit recovery measure is appropriate because under the separate business model the client in effect does discharge the old firm and rehire the partner working on its case. ${ }^{120}$ While theoretically the measure is based on work done rather than on the vagaries of actual recovery, the old partnership is not entitled to any recovery except upon the happening of the contingency. ${ }^{121}$ Furthermore, courts allowing a quantum meruit recovery inay consider more than simply the number of hours spent by each firm in completing the case. Among other factors, they may take into account the difficulty of the case, the quality of the legal work, and the risk and amount of recovery. ${ }^{122}$

In addition to restructuring the allocation of postdissolution fees, the separate business model also affects the general duties owed by partners upon dissolution. Because dissolution and termination are coternninous, the fiduciary duties of partners cease as of the date of

118. See, e.g., Jewel v. Boxer, 156 Cal. App. 3d at 175-76, 303 Cal. Rptr. at 16 (discussing such an allocation made by the trial court); Cofer v. Hearne, 459 S.W. 2d 877, 881 (Tex. Civ. App. 1970). This sort of determination also is made in cases where the client substitutes counsel. In such a case under a contingent-fee contract, the discharged counsel is entitled to a quantum meruit recovery based on the percentage of work done by him im relation to the case as a whole only upon the occurrence of the contingency. See Fracasse v. Brent, $6 \mathrm{Cal}$. 3d 784, 791-92, 494 P.2d 9, 14, $100 \mathrm{Cal}$, Rptr. 385, 390 (1972). Of course, factors other than time are relevant in this distribution. On the other hand, where the attorney is on an hourly-fee contract, the fee is divided as of the time of substitution.

119. See Fracasse v. Brent, 6 Cal. 3d 784, 494 P.2d 9, 100 Cal. Rptr. 385 (1972) (court allowed firm a quantum meruit recovery against client who breached contingent-fee contract, but only upon happening of contigency).

120. Under this model, the old partnership is in fact terminated as of the date of dissolution (except for housekeeping functions like liquidation, payment of debts, collection of acerued fees, and the like) contrary to UNIF. PARTNership ACT § 30, 6 U.L.A. 367 (1969); CAL. CorP. Code $\S 15030$ (West 1977). Because the firm is dissolved, it is no longer capable of doing work for the chent. This is the functional equivalent of a discliarge. The client may then hire whichever attorney he or she wishes to complete the case. This is important because, as the court in Fox v. Abrams, 163 Cal. App. 3d 610, 614, 210 Cal. Rptr. 260, 263 (1985) pointed out, Fracasse only applies where thc client has discharged the attorney.

121. Fracasse, 6 Cal. 3d at 792, 494 P.2d at 14, 100 Cal. Rptr. at 390.

122. While not susceptible of any clear formulation, a quantum meruit recovery is likely to approximate a pro rata split. See, e.g., Los Angeles v. Los Angeles-Inyo Farms Co., 134 Cal. App. 268, 276, 25 P.2d 224, 227-28 (1933). A pro rata split would involve dividing the fees between the old partnership and the attorney based upon the number of hours worked by each. Certainly, the mcasure may vary for extraordmarily ligh or low recoveries. Even this possibility is minimized, lowever, becanse the same attorneys are working on the case before and after dissolution, if only under a different name. 
dissolution. ${ }^{123}$ The dissolving partners would have the same opportunity as the remaining partners to convince the chent to allow them to complete the business. Any attempt by the dissolving partners to draw away clients of the contmuing firm can lead to actions for breach of fiduciary duty and interference with economic relations under the current regime. ${ }^{124}$ Thus, under the separate business inodel, the client's choice is enhanced by the benefits of free competition.

The model also eliminates the potential for lock-in and lock-out. Since there are no disincentives for dissolving, the model ensures that atwill partnerships actually may be dissolved at will. Similarly, partners are not dissuaded from continuing on a given case following dissolution, because they are entitled to receive fees for the full value of their work in the postdissolution period. However, the model may disserve other fundainental policies by increasing tlie risk of grabbing. ${ }^{125}$

\section{The Compensation Model}

The compensation model varies from the separate business model in that it retains the doctrine of unfinished business, but allows a windingup partner to receive compensation where necessary to prevent inequities. Thus, upon dissolution partners are still under a duty to wind up unfinished partnership business for the benefit of the partnership. However, where the unfinislied business is incapable of equal division, a partner wlio assumes a disproportionate burden in winding up is entitled to compensation for the extra effort.

Under the proposed model, the measure of compensation is a function of (1) the amount of work done by the winding-up partner in excess of that done by the other partners, and (2) the expected value of that extra work as of the date of dissolution. Where the separate business model produces a recovery based on the entire ainount of work performed by a partner after dissolution, the compensation model takes account only of postdissolution work done in excess of that performed by the other partners. This excess amount is expressed as that percentage of the total time spent in winding up unfinished busmess during which other partners are no longer working on partnership matters. To arrive

123. Except, of course, for the minor "housekeeping" functions involved in winding up. See supra note 120 .

124. If the dissolving partners seek to take the case before termination, they may be liable for tortious interference witl an economic relationship. To take business away from the partnership is a breacl of fiduciary duty. See Rosenfeld, Meyer \& Susman v. Cohen, 146 Cal. App. 3d 200, 219-21, 194 Cal. Rptr. 180, 191-93 (1983). This is because the partners have a duty to wind up the affairs of the partnership for the benefit of the partnership. See generally UNIF. PARTNERSHIP ACT $\$ 37,6$ U.L.A. 444 (1969); CAL. CORP. CODE $\$ 15037$ (West 1977). Liability for such interference may include loss of future income to the firm as well. See RESTATEMENT (SECOND) OF TORTS $\$ 766$ A (1979).

125. See infra text preceding note 134 . 
at the compensation figure, that percentage is applied to the expected return of that unfinished business as of the date of dissolution. The winding-up partner must then account to the partnership for the remaining amount. ${ }^{126}$

Unlike the separate business model, the coinpensation model does not alter the structure of the current regime with respect to the fiduciary duties of partners during the winding-up period. Dissolution and terinination are not coterminous. Thus, the partnership continues to exist as an entity throughout the winding-up period. Consequently, while dissolving partners can undertake new business for existing clients, they cannot capture unfimished business for their own benefit at the expense of the partnership. ${ }^{127}$

Like the separate business model, the compensation model reduces lock-in and lock-out. Because compensation is available, a partner wishing to dissolve may do so without being subjected to any inequities created by the fortuitous distribution of work within the firm at the given moment. Additionally, a dissolving partner has no reason not to complete a given case after dissolution, since he or she may retain all the benefit derived from the expected returns of any disproportionate work. Of course, a partner may be dissuaded from retaining a large contingentfee case where doing so would create cash flow problems or where it is impossible to spread risks more widely. ${ }^{128}$ A dissolving partner can initigate even this problem, however, by renegotiating the contract with the client, again for the benefit of the partnership, ${ }^{129}$ or by dividing fees earned by other partners "on account" as they are collected.

The application of these two models may be illustrated by returning to our simple hypothetical.

126. The definition of "expected retum" can be troublesonie. It basically is a range estinuated at the time of dissolution as to the fees each case should generate in toto. Any actual recovery within the range is presumably the "expected return" and thus not subject to the risk/windfall spreading effect. See infra text accompanying notes 130-33. If the actual recovery is bclow the range, the difference is the "risk." If above the range, the difference is the "windfall." For an explanation of possible modifications to the concept of expected return where actual return is the only viable method of achieving agreenent among interested parties, see infra note 146.

127. See supra note 124 and acconpanying text; see also Little v. Caldwell, 101 Cal. 553, 36 P. 107 (1894).

128. Large cases often require large staffs. Further, these cases often continue for a nunber of years. During this time, the plaintiff's attorney may be receiving little if any fees, and may never receive a full recovery if there is an unfavorable resolution. A large firm which handles numerous matters simultaneously can better assune the reduced cash flow. In addition, a large flrm is better able to spread the risk of losing a large case. See generally Gilson \& Mnookin, supra note 3.

129. Renegotiation is permissible as long as the partnership fully recovers its share. This can be done in two ways. Either the attorney can simply insure that the full fees of the original contract are paid to the old firm, or, if done in good faith, the whole contract can be renegotiated for the partnership's benefit. See, e.g., Little v. Caldwell, 101 Cal. 553, 36 P. 107 (1894). 


\section{B. Application and Comparison of the Models}

\section{Fee Division Under Each Model}

Returning to our hypothetical involving Alvin, Birney \& Chandler, recall that Chandler dissolved our hypothetical law firm three years after commencernent of the class action suit. She eventually settled the suit two years after dissolution and brought in fees of $\$ 3,000,000$. Alvin and Birney, on the other hand, worked for only six inonths on unfinished business and earned $\$ 300,000$ in fees. During the remaining year-and-ahalf that Chandler was coinpleting the class action suit, Alvin and Birney earned $\$ 1,200,000$ in new business of their own. For purposes of applying the proposed models, assume that one-half of the fees generated by Alvin and Birney in winding up the unfinished business accrued prior to dissolution. Further assume that Chandler coinpleted $60 \%$ of the work on the class action prior to dissolution.

Under the separate business inodel, dissolution serves to transform the partnership business into the separate busmesses of the various partners. Thus, Alvin and Birney inust account to the partnership only for $\$ 150,000$ - one-half of the $\$ 300,000$ generated in coinpleting cases pending upon dissolution. Because the remaining $\$ 150,000$ is attributable to work performed after dissolution, Alvin and Birney need not account to the partnership for that business. Chandler inust account to the partnership for $60 \%$ of the $\$ 3,000,000$ received under the contingent contract, or $\$ 1,800,000$.

Under the separate business inodel, the results of the fee division are quite straightforward. The partners have accounted to the partnership for a total of $\$ 1,950,000$ (\$150,000 froin Alvin and Birney, $\$ 1,800,000$ froin Chandler). Again assummg equal partnership shares and no expenses, each partner may draw $\$ 650,000$ froin the partnership. Thus, Alvin and Birney each earn $\$ 650,000$ from the partnership, $\$ 75,000$ from their unfinished business accruing after dissolution, and $\$ 600,000$ from new business generated on their own-a total of $\$ 1,325,000$ each. Chandler, on the other hand, receives $\$ 1,850,000-\$ 650,000$ froin the partnership and $\$ 1,200,000$ froin work performed on the class action suit after dissolution.

The compensation inodel yields somewhat different results. Since partners are under a duty to coinplete unfinished business for the benefit of the partnership, Alvin and Birney inust account for the full $\$ 300,000$ they collected in winding up and Chandler inust account for the entire $\$ 3,000,000$ received froin the settlement of the class action. Thus, the partnership earns $\$ 3,300,000$.

Chandler, however, is entitled to coinpensation because she worked for two years on partnership affairs after dissolution, while Alvin and 
Birney worked only six months. Assume, for the moment, perfect foresight-that is, the actual fees generated from partnership business equaled the expected value of that business on the day of dissolution. Of the two years Chandler spent completing unfinished business, $75 \%$ of that time, or 1.5 years, was time spent in excess of that spent by Alvin and Birney on partnership matters. Because the actual and the expected value of recovery are equal, Chandler is entitled to draw as compensation $75 \%$ of the postdissolution value of the class action suit. Because Chandler had to account to the partnership for $60 \%$ of the $\$ 3,000,000$ return, she is entitled to $75 \%$ of the remaining $40 \%$, or $\$ 900,000$.

Resolution of the fee-sphitting problem is again relatively straightforward. After Chandler draws her compensation, the partnership retains $\$ 2,400,000$. From this, each partner is entitled to draw $\$ 800,000$. Ultimately, Alvin and Birney earn $\$ 1,600,000$ froin the partnership and $\$ 1,200,000$ from their new business for a total of $\$ 2,800,000$ or $\$ 1,400,000$ each. Chandler earns $\$ 1,700,000-\$ 800,000$ from the partnership and $\$ 900,000$ as compensation.

These models yield very different results from the current regine, with Chandler doing significantly better under either inodel. Chandler earns shightly inore under the separate business than under the compensation model. In both cases, however, she earns more than she would have if the partnership had not dissolved. In that event, she would have received $\$ 1,500,000$ - one-third of the total $\$ 4,500,000$ earned by all partners during the relevant period compared to $\$ 1,850,000$ under the separate business model and $\$ 1,700,000$ under the compensation model. Armed with an understanding of how the models are applied, we now turn to an examination of their underlying attributes.

\section{Comparison of the Models-A Result-Oriented Approach}

The basic structural differences between the separate business model and the compensation model have already been discussed. Under the separate business model, dissolving partners are not obligated to wind up partnership affairs for the benefit of the partnership. While they still owe duties to chients to complete executory contracts, any fees generated in the postdissolution period accrue to the sole benefit of the partner performing the work. Furthermore, because dissolution and termination are simultaneous, dissolution serves to extinguish all fiduciary duties that partners may owe to each other, thereby encouraging free competition for chient business. On the other hand, under the compensation inodel, partners reinain bound to wind up unfinished business for the benefit of the partnership. In addition, the fiduciary duties between partners remain in effect during the winding-up period. The coinpensation inodel, therefore, reduces the incentive for bad faith at dissolution. Moreover, 
under this model a partner may draw compensation to the extent his or her winding-up burden exceeds that of the other partners.

Insofar as the fee-division question is concerned, these differences manifest themselves in two distmct ways-"flattening" and "risk/windfall spreading." Both effects can be illustrated by a modified hypothetical. We now consider the law firm of Davis, Everby \& Femberg-A Partnership Including Professional Corporations.

Davis, Everby \& Femberg is a small, boutique law firm specializing in hitigation. Relations between the three partners have always been harmomous, but recently friction has arisen between them. Because the partners are unable to settle their differences, Feinberg decides to dissolve the firm in good faith and goes into practice on his own.

In the two-year period following dissolution, Davis and Everby collect $\$ 2,000,000$ from the completion of unfinished busmess, which represents one year's worth of work by each. During the same period, they also earn an additional $\$ 1,000,000$ from new busmess entered into after dissolution. Feinberg spends the entire two-year period winding up a large antitrust case and ultimately secures a $\$ 3,000,000$ judgment, which results im $\$ 1,000,000$ in fees at the end of the two-year period.

\section{a. The Flattening Effect}

As in the hypothetical imvolving Alvin, Birney \& Chandler, the postdissolution mcome of a dissolving partner may vary significantly from what it would have been had the partnership stayed together. The compensation model can serve to reduce the disparities by flattening the range of income differentials. Assume im the hypothetical above that one-half of all fees received from unfinished business accrued prior to dissolution, the other half being attributable to postdissolution winding up. Had the partnership not dissolved, the entire $\$ 4,000,000$ earned by the partners during the relevant period would be equally divided among the three partners.

Upon dissolution under the separate business model, however, disparities come into play. Because dissolution transforins partnership business into separate businesses, Davis and Everby need ouly account to the partnership for $\$ 1,000,000$ (the half of the $\$ 2,000,000$ in unfinished business accruing prior to dissolution). Similarly, Feinberg needs account only for one-half of the $\$ 1,000,000$ contingent fee. Thus, the partnership's income of $\$ 1,500,000$ is divided equally among the partners. Ultimately, Davis and Everby each earn a total of $\$ 1,500,000$ (\$500,000 from their partnership draw, $\$ 500,000$ from separate business, and $\$ 500,000$ from new business). Feinberg, on the other hand, earns ouly $\$ 1,000,000$ $(\$ 500,000$ from his partnership draw and $\$ 500,000$ from transforned separate business). 
The compensation model minimizes this disparity. Since partners' duties continue throughout the winding-up period, Davis and Everby must account to the partnership for the full $\$ 2,000,000$ received from completing unfinished business. Femberg likewise must account for the entire $\$ 1,000,000$ contingent fee. Thus, the partnership "pot" contains $\$ 3,000,000$. However, Femberg may deduct compensation, since he spent two years wimding up the affairs of the partnership while Davis and Everby each spent only one. Thus, 50\% of the time spent by Feinberg in completing unfinished business was time spent im excess of that spent by the other partners. Assuming again that the actual fees realized were the expected fees as of the date of dissolution, Femberg's compensation would be $\$ 250,000$ ( $50 \%$ of $50 \%$ of $\$ 1,000,000)$. Thus, $\$ 2,750,000$ is available for distribution by partnership share. Consequently, Davis and Everby earn roughly $\$ 1,415,000$ each (their partnership imterests plus their new busmess), while Femberg earns roughly $\$ 1,170,000$ (his partnership interest plus compensation).

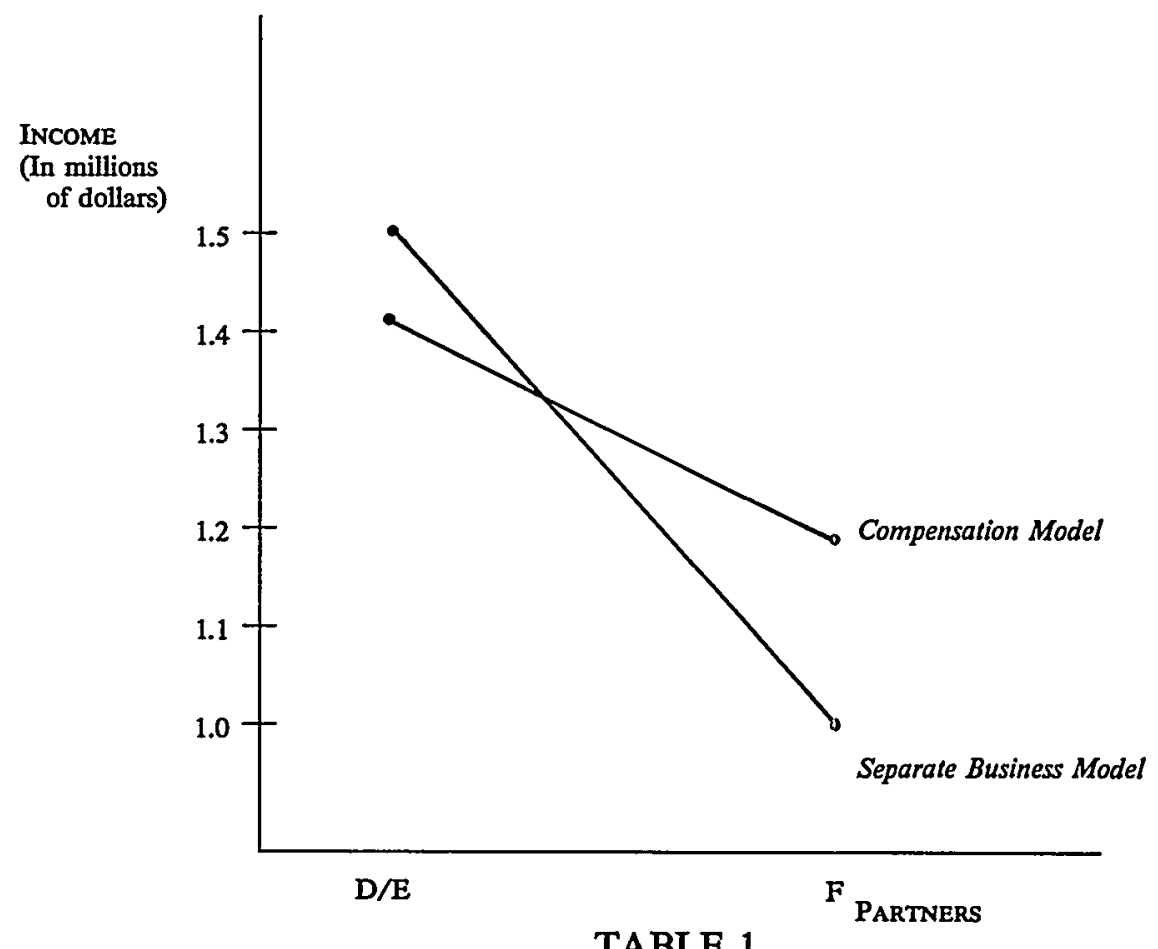

As Table 1 illustrates, the compensation model tends to flatten the mcome disparities of partners in the postdissolution period relative to those resulting under a separate business model. Under a separate business model, disparities arise as of the date of dissolution because business 
is transformed into the separate businesses of the individual partners at that time. Under the compensation model, however, partners continue as partners for the purpose of winding up the partnership affairs. Any incoine disparities brought about by new business or compensation do not arise until sometime after dissolution. Until that time, fees are, in effect, allocated as if the partnership still existed. Thus, the compensation model brings partners closer to their original partnership shares than does the separate business inodel.

In considering this flattening effect, it is important to note that in the hypothetical, Feinberg is not as productive in the postdissolution period as are Davis and Everby. Thus, he does better under the compensation inodel, because it delays the effective date of separate earnings. In the previous example, however, Chandler was inore productive than either of her former partners. Thus, in that case, she fared better under the separate business inodel. Consequently, neither model uniformly favors either the dissolving or reinaining partners.

As seen earher, there are two inajor differences between the separate business inodel and the compensation inodel. First, the compensation inodel tends to delay the termination of the partnership by requiring partners to wind up unfinished business for the benefit of the partnership. The separate business inodel, on the other hand, accelerates termination by eliminating winding up in the postdissolution period. As deinonstrated above, this delay serves to flatten the incoine differentials among partners immediately following dissolution. Second, the separate business inodel allows partners to retain the benefits of actual recovery in the postdissolution period. The coinpensation model provides for coinpensation based on the expected value of recovery as of the date of dissolution. This latter difference gives rise to another attribute of the coinpensation model-the risk/windfall spreading effect.

\section{b. The Risk/Windfall Spreading Effect}

The previous hypotheticals assumed perfect foresight-the actual recoveries equaled the expected recoveries as of the date of dissolution. This often may not be the case. Early projections of the expected value of a case can turn out to be high or low. The risk of overestimating the expected recovery nay cause a dissolving partner to hesitate before agreeing to undertake the completion of a large case. If the chance of victory is slim, the dissolving partner inay be disinclined to complete the case and would probably prefer to pass the risk of loss to the firm. In the two previous hypotheticals, Chandler and Feinberg were left with large cases upon dissolution which required their full-time attention in the postdissolution period. Had they considered the risk of losing to be relatively high, they might well have refused to coinplete their cases, thereby 
preventing the chent from retaining its attorney of choice. Thus, the risk that the partners were willing to undertake as a group inay simply be too high for a single partner to undertake. ${ }^{130}$

Conversely, the partners may underestimate the recovery and subsequently find that the actual recovery exceeds the expected recovery. In effect, a windfall occurs; the partners recover inore than was necessary to prompt them to undertake the risk. Often, this windfall may occur due to factors unrelated to the skills and abilities of the partners.

The compensation model, however, reduces these problens by distributing the risks and windfalls associated with unfinished business among the partners of the dissolved firm. This phenornenon can be illustrated by returning to our hypothetical involving Davis, Everby \& Feinberg.

i. Risk spreading. Recall that in the two-year period following dissolution, Davis and Everby collected $\$ 2,000,000$ from the completion of unfinished business, which represented one year's worth of work by each. During the same period, they earned an additional $\$ 1,000,000$ froin new business entered into after dissolution. Feinberg spent the entire twoyear period winding up a large case. Recall also that one-half of all fees collected on unfinished business accrued prior to dissolution. Assume now that the expected value of Feinberg's case on the date of dissolution is $\$ 2,000,000$ rather than $\$ 1,000,000$. Assume further that instead of winning the case and bringing in $\$ 1,000,000$, he loses and brings in nothing. This scenario drastically affects the imcome-distribution patterns of the various partners.

Under the separate business model, the entire risk of an overestimate is shifted upon dissolution to the winding-up partner, because the case becomes the partner's separate business on that date. Under the facts of the modified hypothetical, Feinberg earns roughly $\$ 333,000$ (onethird of the partnership income) during the two-year period following dissolution. On the other hand, Davis and Everby each earn approximately $\$ 1,333,000$ comprised of their partnership shares $(\$ 333,000)$, their transforned separate business ( $\$ 500,000 \mathrm{each})$, and their new business $(\$ 500,000$ each).

However, the compensation model apportions the risk of a high estimate among all the partners of the dissolved firm. Under the modified hypothetical, Davis and Everby account to the partnership for the full $\$ 2,000,000$ collected from the coinpletion of unfinished business. Feinberg collects no fees and thus need not account to the partnership. Thus, the partnership income is $\$ 2,000,000$. Nevertheless, Feinberg is entitled to compensation based on the expected return of $\$ 2,000,000$

130. See Gilson \& Mnookin, supra note 3, at 8-18. 
(assuming that the actual loss is not attributable to Feinberg's own negligence). ${ }^{131}$ Thus, before each partner draws a share, Feinberg may deduct compensation of $\$ 500,000$ (50\% of $50 \%$ of $\$ 2,000,000)$. Each partner thus is left with a $\$ 500,000$ partnership share. Davis and Everby together ultimately receive $\$ 2,000,000(\$ 1,000,000$ from their partnership shares and $\$ 1,000,000$ from new business), while Femberg receives $\$ 1,000,000$ ( $\$ 500,000$ from his partnership share and $\$ 500,000$ in compensation).

The ability of the compensation model to distribute the risks of high estimates among the dissolving partners is illustrated by Table 2 below. Under the separate business inodel, Feinberg assumes the brunt of the realized risk, which is represented by distance $y$ in Table 2 . Under the compensation model, part of that risk is spread between Davis and Everby as well, as shown by distance $x$ in the table.

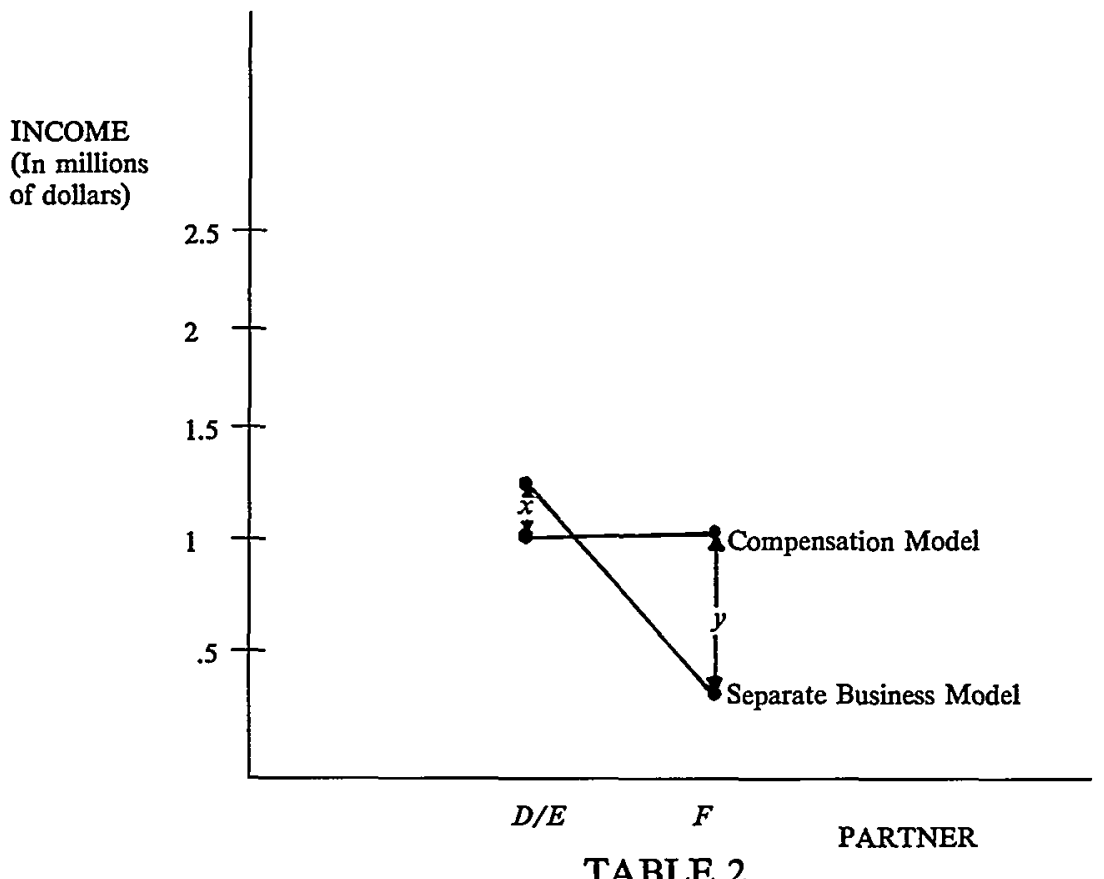

As Table 2 illustrates, the compensation model serves to place the risk of a high estimate upon the partnership that originally agreed to

131. Normally, the risks and windfalls are spread to all inembers of the partnership. However, where the loss is due to tlie negligence of the attorney ratlier than unforeseen events, it seems unfair to force tlie nonnegligent partners to absorb the liarm, at least after dissolution. Thus, in that case, the actual recovery would be used to determine coinpensation. As sucl, although some of the negligently caused loss passes through to other partners (since the nonneghigent partners inust still give soine compensation from other eases to the negligent partner), the brunt is borne by the negligent partner. 
undertake that risk. The partnership may have taken the risk only upon the knowledge that any potential loss would be spread among all three partners. In effect, that decision was made by the partnership based on the combined strength of all the partners. Because the partnership as a whole accepted that risk, it is only fair that the partnership should share in any loss that occurs.

ii. Windfall spreading. Some cases produce recoveries beyond the most optimistic expectations. Postdissolution discovery may reveal previously missing evidence. Juries may defy prediction. Whatever the reason, the excess recovery is a windfall; it is not needed to induce the partners to take the case. A final visit to Davis, Everby \& Feinberg reveals that the compensation model equitably distributes such windfalls as well.

Assume that two years after dissolution, Feinberg uncovers an incriminating memorandum. Consequently, he settles the case for $\$ 4,000,000$ rather than the expected $\$ 2,000,000$-resulting in a windfall of $\$ 2,000,000$.

Under the separate business model, Feinberg is able to capture the hon's share of the windfall. ${ }^{132}$ Davis and Everby contribute $\$ 1,000,000$ to the partnership mcoune and Feinberg contributes $\$ 2,000,000$ (50\% of the $\$ 4,000,000$ settlement). Consequently, Davis and Everby together earn $\$ 4,000,000$ during the relevant two-year period- $\$ 2,000,000$ froin their partnership shares, $\$ 1,000,000$ from their transformed separate business, and $\$ 1,000,000$ froin new busmess. Feinberg draws a partnership share of $\$ 1,000,000$ and retains $\$ 2,000,000$ froin transformed separate business-a realization of $\$ 3,000,000$.

The compensation model redistributes the windfall among the former partners of the firm. Davis, Everby, and Feinberg each account to the partnership for fees received from unfinished business-a total of $\$ 6,000,000$. While Feinberg is entitled to compensation, the measure is based on the expected recovery of $\$ 2,000,000$. Thus, Feinberg's compensation is $\$ 500,000$ (50\% of $50 \%$ of $\$ 2,000,000)$. Accordingly, Davis and Everby earn roughly $\$ 4,667,000$ ( $\$ 1,833,000$ each or $\$ 3,667,000$ combined from their partnership shares and $\$ 500,000$ each froin new business). Feinberg realizes roughly $\$ 2,333,000$-a partnership share of $\$ 1,833,000$ plus compensation of $\$ 500,000$.

Table 3 demonstrates the windfall-spreading effect of the coinpensation model. Under the separate business model, Feinberg is able to cap-

132. Under one scenario, Davis and Everby may succeed in having the entire recovery prorated equally over the life of the case. Under another scenario, Feinberg may succeed in claiming that the entire value of the windfall accrued in the postdissolution period and therefore is not subject to a partnership accounting. We will assume for purposes of example that the entire recovery is prorated over the pre/postdissolution period. 
ture the greater portion of the windfall-distance $y$ in Table 3. However, under the compensation inodel, a portion of the windfall is distributed among Davis and Everby as well-distance $x$ in Table 3.

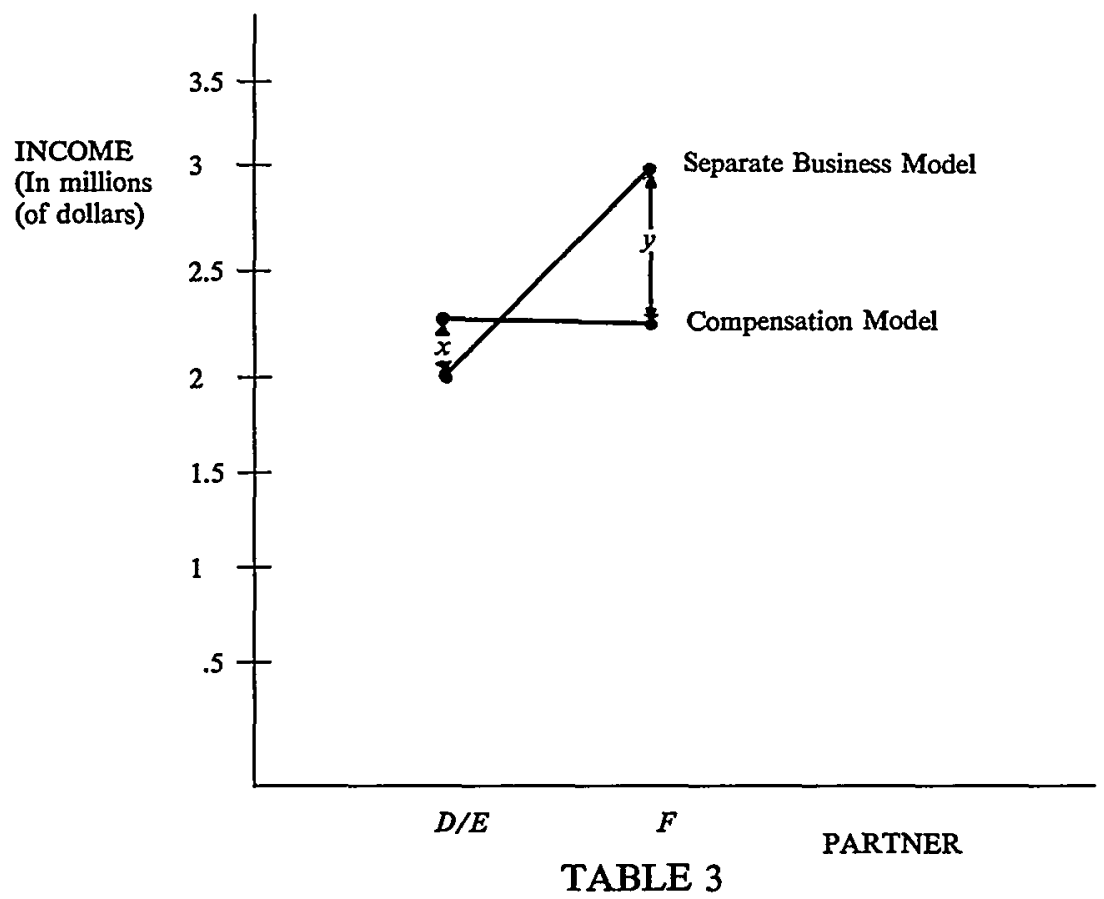

Viewing the compensation model by itself, the equities of windfall spreading are apparent. Because the partnership absorbs the risk of overestimates of the value expected when calculated at dissolution, it deserves the benefits accompanying underestimates.

But the qualities inherent in windfall-spreading extend beyond the compensation model's internal consistency: they go to the heart of the model's rationale. Coinpensation is awarded ouly to the extent necessary to correct for the inequities that lead to lock-in and lock-out. No inequities are created by a refusal to award unearned income. While a partner may argue that the windfall was earned due to his or her personal skill (in this case diligence in discovering the missing evidence), that skill was taken into account in calculating the expected recovery. Since it is the expected value of a matter viewed ex ante that affects a partner's casetaking decision, actual values determined ex post are irrelevant to the concerns of lock-in and lock-out. ${ }^{133}$

With this basic understanding of the characteristics of each model, it is possible to determine which inodel best serves the policy goals outlined

133. Because both the loss and the windfall were unexpected by definition, they probably were not figured directly into the partners' dissolution decision. See supra note 126. 
in Part I: the preference of at-will partnerships as an element of freedoin of contract, the enforceinent of fiduciary duties that discourage grabbing, and the wide latitude given to chents to choose counsel freely.

\section{IV \\ Balancing Social Values}

In Part III, this Comment defined and coinpared two alternatives to the current systein. Section $A$ of this Part examines the policy considerations of these alternatives and argues that the compensation model best addresses the phenomena of lock-in and lock-out on the one liand and grabbing on the other. Section $B$ proposes a inodification of the coinpensation model that would permit an exception for bad faitl dissolutions. Finally, Section $C$ discusses the optimal inethod for implementing the compensation inodel.

\section{A. Comparison of the Models-A Policy-Oriented Approach}

The separate business inodel is grounded upon the theory that if a dissolution occurs in good faith, eacli partner sliould be able to retain the benefits that his or her mdividual skill and labor contributed toward coinpletion of a case. While it is true that the old firm negotiated the contract with the chent, the former partners are fully compensated when the partnership receives its recovery.

Whether or not the separate business model fares better than the current regime in achieving the proper balance of policy objectives may well be a inatter of judgment. That determination is no doubt tempered by perceptions as to the relative importance of eacli of the various competimg poticies. The inodel clearly eliminates the concerns of lock-in and lock-out. Because there are few dismcentives for dissolving, the model preserves the preference for at-will partnerships. Similarly, the partners are not dissuaded froin contmumg on a given case following dissolution, because they are entitled to receive fees for the full value of their work in the postdissolution period.

Nevertheless, where the potential for postdissolution profit is great, a partner may be tempted to dissove the partnership in order to capture the benefits of particularly lucrative cases. In such an event, the separate business inodel fails to serve the fiduciary principles ained at preventing grabbimg. Thus, while the current regime elevates the policy aimed at preventing grabbing above the policies favoring at-will partnerships and chent choice, the separate busmess inodel inay do no more than reverse the existing preferences.

Perhaps inore than any other factor, concern about grabbing has led 
the courts away from limiting the doctrine of unfinished busimess. ${ }^{134}$ For example, in Rosenfeld, Meyer \& Susman v. Cohen, ${ }^{135}$ the California Court of Appeal rejected the dissolving partners' argument that the former law partnership was entitled to only a quantum mernit recovery from fees received in a postdissolution settlement of a large contimgentfee case. The court indicated that allowing the forner firm only a quantuin meruit recovery would be mequitable, because the fornier firm had carried the case for a number of years while receiving no fees. ${ }^{136}$ The dissolving partners, on the other hand, assumed very hittle risk, drawing their partnership shares during the relevant period, and then seeking to take over the case at a time when recovery was almost certain. ${ }^{137}$ The events surroundimg the dissolution strongly indicated that the dissolving partners had acted in bad faith by attempting to grab the benefits of a lucrative case at a time when the partnership was particularly vulnerable. While this factor no doubt influenced the decision, the court did not anchor its holding on this ground. Instead, the court found a quantuin meruit recovery inequitable and contrary to the concept of unfinished business. ${ }^{138}$ The partnership had a contractual expectancy in the ultiInate recovery, and aceording to the court such an expectancy should not be apportioned aceording to the amount of work done before and after the dissolution.

The current regime's einphasis on discouraging grabbing to the exclusion of other pohicy goals inay be unwarranted for several reasons. Most important, it is unclear that strict adherence to the unfinished-business doctrine adds any deterrent force to the law's anti-grabbing arsenal that does not already exist. Page inakes clear that even an at-will partnership may not be dissolved in bad faith. ${ }^{139}$ Thus, even under a separate business inodel, partners probably would be discouraged froin dissolving simply to capture the benefits of particularly lucrative cases. To do so would render thein hable to their partners for breach of a fiduciary duty. ${ }^{140}$ The measure of damages in such a case would equal at least the

134. See, e.g., Jewel v. Boxer, 156 Cal. App. 3d 171, 179, 203 Cal. Rptr. 13, 18-19 (1984); see also supra text accompanying note 113.

135. 146 Cal. App. 3d 200, 194 Cal. Rptr. 180 (1983).

136. Id. at 209, $194 \mathrm{Cal}$. Rptr. at 184-85.

137. Id. at 209-10, 194 Cal. Rptr. at 185.

138. Id. at $216-20,194 \mathrm{Cal}$. Rptr. at 190-92.

139. Page v. Page, 55 Cal. 2d 192, 197-98, 359 P.2d 41, 44-45, 10 Cal. Rptr. 643, 646-47 (1961) (Traynor, J.). Page held that while a partnership at-will can be dissolved for any reason or for no reason, it must not be dissolved in bad faith. Dissolution for personal gain at the expense of the partnership constitutes bad faith. This rule was reiterated in Leff v. Gunter, $33 \mathrm{Cal}$. 3d 508, 658 P.2d 740, 189 Cal. Rptr. 377 (1983), where the defendant dissolved a partnership at-will that was bidding on a project in order to bid on it for himself. The court found the dissolution to have been in bad faith. In Leff, however, there was no unfinished busmess to complete.

140. Partners are fiduciaries for purposes of winding up until termination of the partnership. See UNIF. Partnership ACT $\S \S 21,30,6$ U.L.A. 258, 367 (1969); Cal. CoRP. Code $\$ \S 15021$, 
loss of fees brought about by the bad faith dissolution. Furthermore, the fee-allocation formula used under a separate business inodel may even out any inequities that otherwise might result froin an untimely dissolution, thereby reducing the incentive for grabbing. The separate business model's quantum ineruit recovery takes into account a panoply of factors-time, risk, difficulty, and quality. Thus, where a dissolution takes place "after the jury retires," it is unlikely that the dissolving partners could capture a significantly greater portion of the ultimate recovery.

However, the separate business model's emphasis on preventing lock-in and lock-out, even at the expense of encouraging grabbing, seeins reasonable in many situations. In a good faith dissolution, it is unclear that separation would occur shortly before the conclusion of a inajor case, when the risk factor is at a minimum. It may well occur near the beginning stages of a case, where the risk tends to be quite high. In such a case, it would be inequitable to allow the partnership to retain all of the benefits while assuming hittle of the risk. While in theory partners are fiduciaries and, as such, inay not force a dissolving partner to undertake a disproportionate burden in winding up, equal division of the workload may be impossible where cases vary in size and stage of completion. ${ }^{141}$ Thus, a dissolving partner who bears an inequitable burden cannot sue his partners for bad faith when it is impossible to divide equitably the postdissolution burdens. Consequently, the separate business model provides a inechanisin to correct for grabbing that is unavailable to correct for lock-in and lock-out under the current regime.

Of course, the requireinent of good faith under a separate business model will not eliminate coinpletely the potential for grabbing. Indeed, grabbing may occur even under the current regime. ${ }^{142}$ Whether a partner has dissolved in bad faith is a question of fact. Resolution of the question is subject to the constraints of a fact-finding systein. Partners often may have mixed inotives for dissolving a partnership. In soine cases, the circuinstances surrounding dissolution will clearly establish bad faith. In other cases, the inferences inay not be so compelling. Perhaps the only certainty inherent in the process is that a final determination of a partner's motives will be both time-consuining and expensive. At least to soine extent then, the unfinished-business doctrine of the current regime better serves fiduciary goals than does the separate business model.

This trade-off between grabbing on the one hand, and lock-in and

15030 (West 1977); see supra note 117. Dissolving in order to capture the benefits of lucrative cases would be a bad faith dissolution which would subject then to damages. See also Leff v. Gunter, 33 Cal. 3d 508, 658 P.2d 740, 189 Cal. Rptr. 377 (1983).

141. See supra note 117 and accompanying text.

142. See generally Gilson \& Mnookin, supra note 3. 
lock-out on the other, suggests a compromise. The risk of grabbing is most severe where there are no constraints or disincentives associated with dissolution. Lock-m and lock-out become significant where dissolution imposes hardships on a dissolving partner. The preferable inodel then, is the one that minimizes the combined effects of all three phenomena-the model capable of achieving result $X$ in Figure 1 .

Although a precise calculation of where each of the various models fits on the scale illustrated in Figure 1 would be very difficult, it may be possible to predict the relative range of results that each model should produce. The current system minimizes grabbing, but fails to account adequately for lock-in and lock-out. The separate busmess model removes all disincentives for dissolution, which thereby potentially increases the risk of grabbing. The coinpensation model, however, alleviates some of the hardships imposed by the current system (by awarding compensation where necessary to prevent inequity), but restricts the possibilities for grabbing (by requiring partners to wind up unfinished business for the benefit of the partnership). Further, it preserves the law's preference for at-will partnerships. Consequently, the coinpensation model should fall somewhere between the separate busmess model and the current regime.

Figure 1 illustrates that the compensation model minimizes the combined inefficiencies associated with dissolution. This conclusion is subject to a few important caveats. First, the shape of the curves is assumed, not proved. Thus, while the figure illustrates the inverse relationship between lock-in/lock-out and grabbing, it does not purport to predict the elasticity of the trade-off; the percentage increase in one inefficiency resulting from a percentage reduction in the other is a question the model leaves unresolved. The inability to determine with exactitude the shapes of the various curves should not alter the logical underpinnings of the trade-off analysis. The model reasonably assumes that the shape of the curves is roughly hyperbolic. Thus, at some point the curves become increasingly inelastic. A marginal percentage reduction in one inefficiency is achieved ouly by an increasing marginal expense in terms of the other. ${ }^{143}$

As a second caveat, Figure 1 illustrates only the tradeoff between the identified probleins. Other factors are certain to bear upon the desirability of any given model-most notably, the judicial costs associated with

143. For example, the complete elimination of lock-in or lock-out may require the total abrogation of all fiduciary relationships between partners. In such a case, partners truly could dissolve at will, even in bad faith, and actively bid for chients prior to dissolution. Such a system has costs in terms of grabbing which society might well view as wholly unacceptable. Conversely, the imposition of an onerous tax on partners who dissolve and take clients, even in good faith, may deter grabbing significantly. Nevertheless, the cost in terms of lock-in/lock-out would be enormous. 


\section{Probability of}

OCCURRENCE

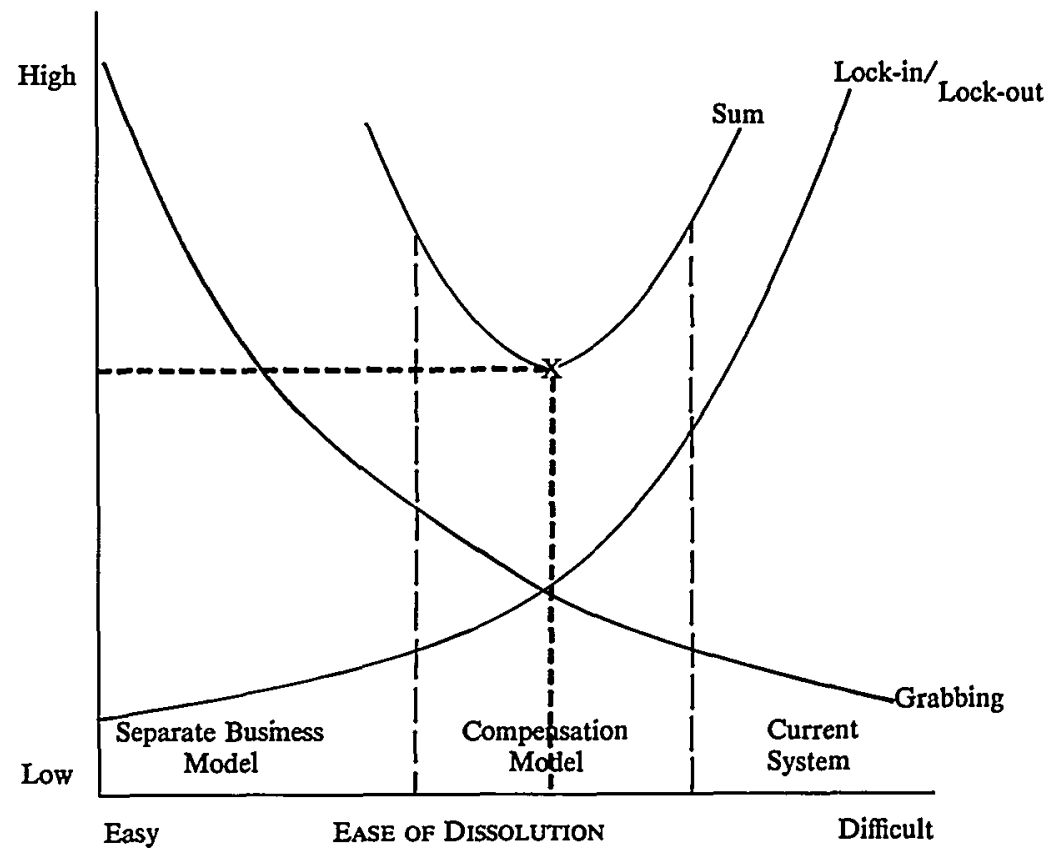

FIGURE 1

implementation of each alternative. The value of this caveat, however, is not confined to defining the limitations of the tradeoff analysis as an illustrative tool. This consideration lays bare the practical constraints of any judicially supervised compensation scheine: the costs in terms of societal resources. While a tradeoff analysis can identify the model that ininimizes the targeted problems, it cannot predict the external cost of implementing that model or justify the assumption of that cost once so determined. Nevertheless, it is possible to estimate the relative costs of each model. Moreover, there are sound reasons for considering a compensation scheme despite its need for judicial supervision.

As noted earher, the Jewel court based its refusal to award coinpensation to a winding-up partner, in part, on notions of "freedom of contract." 144 The court reasoned that if the no-compensation rule operates inequitably, partners are free to contract to vary the results. Courts, on

144. 156 Cal. App. 3d 171, 179-80, 203 Cal. Rptr. 13, 18-19 (1984).

[P]artners are free to include im a written partnership agreement provisions for completion of unfinished business that ensure a degree of exactness and certainty unattainable by rules of general apphication. If there is any disproportionate burden of completing unfinished business here, it results from the parties' failure to have entered into a partnership agreement which could have assured such a result would not occur. The former partners must bear the consequences of their failure to provide for dissolution in a partnership agreement.

Id. at 179-80, 203 Cal.Rptr. at 19. 
the other hand, should not become involved, but should leave the parties where they left themselves.

The current system may better preserve scarce judicial resources than does either of the alternative models. By dissallowing compensation, the current systein may encourage partners to protect against potential inequities in their partnership agreements. Furthermore, the current systein presumes that all business entered into prior to dissolution is partnership business. Thus, partners must account to the partnership for all fees collected from such business; the courts need not involve themselves in a case-by-case determination of the allocation of fees between the partners. The net effect of the current regime may be to encourage private settlement of dissolution disputes, thereby eliminating the burdens on the taxpayers and the courts.

Both the separate business model and the compensation model are likely to involve the courts im dissolution disputes to a greater degree than does the current system. The separate business model requires a determination of what percentage of a given fee accrued before and after dissolution. Partners may ask a court to make that determination when they cannot agree among themselves. ${ }^{145}$ The compensation model may require even closer supervision. Partners may not only disagree as to the expected value of a case, but may ask a court to determine the percentage of time some partners spent winding up unfinished business while others were working on nonpartnership matters. ${ }^{146}$ Thus, the social costs of implementing a compensation scheme inust be balanced agamst the need to prevent lock-m and lock-out. If the private-contract alternative can adequately preserve at-will partnerships and client choice, while minimizing the use of judicial resources, the desirability of a compensation scheme becomes doubtful.

There are, however, serious reasons to question the viability of the

145. This in fact was done in Jewel v. Boxer at the lower court level, reported in the appellate opinion at $156 \mathrm{Cal}$. App. 3d 171, 175-76, $203 \mathrm{Cal}$. Rptr. 13, 16 (1984), and in Fox v. Abrams at the lower court level, reported in the appellate opinion at $163 \mathrm{Cal}$. App. 3d 610, 613-14 \& n.3, $210 \mathrm{Cal}$. Rptr. 260, 262-63 \& n.3 (1985). This approach is essentially a quantum ineruit one. See supra notes $118-19$ and acconipanying text.

146. This estimate can be problentatic. Each party has an interest in maximizing or minimizing this range, though both sides should be able to negotiate a range, perhaps with the help of an accounting firm. No precise estimation is needed at this stage, ouly a reasonable range. See supra note 126. For smaller cases, partners inight well follow the pattern set in Lyon v. Lyon, $246 \mathrm{Cal}$. App. 2d 519, 54 Cal. Rptr. 829 (1966), where the partners simply divided up the unfinished business of the hourly fee clients. Thus, dispute should arise primarily when a large contingent-fec case is involved. Of course, there may be cases where the partners simply cannot agree. Further, the cost of reaching agreement on the estinuates may be high even if agreement is ultimately achieved. However, an alternative exists. The compensation model can be altered to allow compensation to be based on the actual, rather than the expected return. The advantage of this solution is its easy implententation. However, iniplementing such a change will eliminate the risk/windfall spreading effect described supra pp. 1627-32. (although it will not effect the flattening effect described supra 
private-contract alternative. Given the reality of lock-out, clients may bear the burden of the attorneys's failure to contract for compensation. Thus, although the law generally may favor leaving the parties to the terms of their agreements, ${ }^{147}$ clients are not parties to attorney partnership agreements. Nevertheless, it is the clients that are locked-out by the current system's refusal to allow compensation to a partner who must bear inequitable winding-up burdens. While the expense of judicial involvement may justify leaving parties to bear the burdens of their own misguided contracts, such a justification is less persuasive when the burden falls on an innocent third party.

\section{B. Bad Faith Exception to the Compensation Model}

As discussed earlier, partners are fiduciaries, and while a partner may dissolve an at-will partnership for any reason or no reason, he or she may not dissolve in bad faith: e.g., to grab partnership business. ${ }^{148}$ This principle is sound. The presumption in favor of at-will partnerships rests on contract principles: if a partner did not exphicitly or by clear implication agree to remain in a partnership, he or she should be free to leave. Aside from notions of individual freedom, economic efficiency concerns underlie the basic theory. ${ }^{149}$ The removal of artificial barriers allows capital, including human capital, to seek its most profitable investment. In a bad faith dissolution, grabbing is not an incidental inefficiency associated with the break up; it is the moving force behind it. To allow a partner to grab at will the fruits of the combined partners' trust does nothing to promote efficient resource allocation. On the contrary, it can only deter the aggregation of resources necessary to undertake larger and more productive projects.

The logic of the good faith/bad faith distimction becomes even more compelling under a compensation model. As noted, the current system's myopic focus on the fiduciary aspects of dissolution may be unwarranted because the potential damages resulting from a bad faith dissolution probably are adequate to deter inost instances of grabbing. ${ }^{150}$ Nevertheless, the compensation model risks increased grabbing in order to reduce lock-in and lock-out. This increased risk of grabbing brought about by the allowance of compensation necessitates retention of a bad faith

pp. 1625-27. As an alternative, the parties can agree to use the actual recovery instead of the expected recovery. This is especially useful if an expected recovery cannot be determined at the time of dissolution, but rather is reconstructed as the compensation is withdrawn.

147. See Jewel v. Boxer, 156 Cal. App. 3d 171, 179-80, 203 Cal. Rptr. 13, 18-19 (1984).

148. See supra notes $26-30$ and aecoinpanying text.

149. The theory is that people work best in voluntary working relationships, especially where they inust rely on each other. Where such relationships are acrimonious, a disproportionate annount of time is spent on decisionmaking and dispute resolution. See Hillman, supra note 18, at 31 .

150. See Hillman, supra note 18, at 31 . Professor Hillınan argues that the bad faith exception under Page may deter grabbing more than is necessary. 
exception. Furthermore, the purpose of compensation is to prevent inequities that give rise to lock-m and lock-out. When a partner dissolves to usurp a partnership asset, compensation does not prevent mequity, but enhances it.

Nevertheless, the potential consequences flowing from a findimg of bad faith can have significant effects on a partner's willingness to risk dissolution and continue working for a given chent. The bad faith exception may seriously mcrease the chances of lock-m and lock-out im two ways. First, a finding of bad faith may lead to more than a denial of compensation; it may bring about punitive measures as well. Second, the risk of a finding of bad faith hes with the dissolvimg partner; normally, a fiduciary inust justify his or her actions if challenged by the other partners. Thus, fear of a finding of bad faith may have a chilling effect on a partner's decision to dissolve.

The degree to which the bad faith exception aggravates the risk of lock-im and lock-out depends partly upon the measure of damages likely to result from an adverse finding. At a minimum, a partner dissolving $\mathrm{m}$ bad faith would be hable for all fees generated by the usurped busmess. ${ }^{151}$ Under a compensation model, this amounts to a denial of compensation regardless of whether or not the dissolving partner expended a disproportionate amount of work in winding up unfinished partnership business. Denial of compensation itself, however, would give the same result as a good faith distribution under the current system. However, it is possible that courts might impose more severe sanctions.

In the corporate rather than partnership context, at least one court has instituted a distribution of shareholder benefits that denied on equitable grounds participation by shareholder defendants who had diverted those benefits. ${ }^{152}$ There is no reason why this remedy could not be apphied in a partnership context as well. In fact, the partnership context provides stronger support for such a remedy, because partners are generally held to more stringent fiduciary duties than are shareholders. In addition, a tort measure of damages may displace the usual contract measure, because a bad faith solicitation of chients can lead to an action for interference with contractual relations. ${ }^{153}$ These augmented damage

151. This assumes that the loss of such fees is directly caused by the defendant's tortious conduct.

152. See Perlman v. Feldmann, 219 F.2d 173, 178 (2d Cir. 1955).

153. See Rosenfeld, Meyer \& Susman v. Cohen, 146 Cal. App. 3d 200, 220-23, 194 Cal. Rptr. $180,192-94$ (1983). In that case, the dissolving partners committed a tort by encouraging the chient to terminate its contract with the firm. Where such conduct occurs prior to the dissolution, the defendant might be hable for the full expected net value of the chent's busimess. See RESTATEMENT (SECOND) OF TORTS $\S 766 \mathrm{~B}$ (1977). The fact that the chent can terminate the contract at will is irrelevant to the issue of hability. See Speegle v. Board of Fire Underwriters, $29 \mathrm{Cal} .2 \mathrm{~d} \mathrm{34,} \mathrm{39,} 172$ P.2d 867, 870 (1946) (Traynor, J.); Skelly v. Richman, 10 Cal. App. 3d 844, 862, 89 Cal. Rptr. 556, 569 (1970). 
measures, however, may act to exacerbate the concerns of lock-in and lock-out.

These concerns become more significant when one considers the normal rule that a fiduciary has the burden of proving his or her own good faith. ${ }^{154}$ The issue of bad faith is a question of fact. Therefore, because factfinders occasionly make mistakes, a partner dissolving in good faith undertakes a risk of substantial financial consequence. Given the burden of proof allocation, it is easy to allege a bad faith dissolution even if there is only shight evidence or even no evidence to support the allegation. ${ }^{155}$ This low threshold may encourage bad faith clains when the dissolution is not amicable. This in turn can lead to an additional deinand on judicial resources and increase the risk of lock-in and lockout.

Given the need to minimize the potential for lock-in/lock-out and grabbing, the compensation model proposed by this Comment would retaim the bad faith exception, but would place the burden of proving bad faith on the partner asserting it. Several considerations warrant this approach. The discussion above already has alluded to the first of these. Lock-in and lock-out become serious threats when a dissolving partner is constantly in fear of having to justify the motives behind dissolution. Even where a partner can sustain the burden, the expense of a lawsuit may serve as a significant deterrent.

More importantly, the consequences of factinder error warrant shifting the burden to the nondissolving partners. If the factfinder errs in favor of the dissolving partner by finding good faith where there was bad faith, the remaining partners lose hittle under a compensation inodel. While the dissolving partner is able to demand compensation for any disproportionate work, the reinaining partners still receive the full benefits of fees received during the common winding-up period, and they retaim all fees from new business as well. ${ }^{156}$ On the other hand, if the factfinder errs on the side of the nondissolving partner, by finding bad faith where there was none, the dissolving partner may suffer significantly under the compensation model. A partner dissolving in good faith has a legitimate expectation of receiving compensation for any disproportionate work. Demial of such compensation after the partner has invested what may be substantial amounts of time could lead to severe hardship. The possibility of additional damages beyond a denial of compensation may make the risk unbearable. Thus, while a bad faith exception is necessary to insulate the compensation model agamst the risk of increased

154. See, e.g., Laux v. Freed, 53 Cal. 2d 512, 522, 348 P.2d 873, 878, 2 Cal. Rptr. 265, 270 (1960).

155. See Hillman, supra note 18 , at 31 n.97.

156. See infra text accompanying notes $126-29$. 
grabbing, shifting the burden of mvoking the exception minimizes the potential for lock-in and lock-out.

\section{Implementing the Compensation Model}

The language of the Uniform Partnership Act is unequivocal: it denies compensation to all but a surviving partner. ${ }^{157}$ Thus, as a matter of statutory interpretation, the $\mathrm{Jewel}^{158}$ court was justified in labeling the Cofer ${ }^{159}$ decision "plainly wrong." 160 The explicit inclusion of a single exception suggests that the legislature intended to leave no room for others. And while this Comment has suggested law partnerships are unique, the Uniform Partnership Act defines "business" as "every trade, occupation, or profession." 161 Courts have avoided this statutory barrier, however, by limiting the scope of the unfinished-business doctrime. ${ }^{162}$ Thus, winding up would be limited to collecting outstanding claims, paying debts, and distributing the surplus among the partners. As such, conpleting a case would not be considered winding up, but rather, new business.

Effectuating such a suggestion would be tantamont to adopting the separate business model. In fact, the courts favorimg such an interpretation have all einployed variations on that model. ${ }^{163}$ In contrast, implementation of the compensation model, which retams the principles of winding up and unfinished business in the context of law partnership dissolutions, would require wholesale judicial redrafting of a fairly clear statute. Thus, the courts are unable to effectively implement the preferred model on their own initiative.

Creative statutory interpretation perhaps could overcome these obstacles if the inequities bear heavily enough on the judicial conscience. Nevertheless, the legislature is the proper branch to impleinent the compensation model. The legislature is equipped to weigh the alternatives and to strike an appropriate balance between lock-in/lock-out and grab-

157. Unif. Partnership Act $\S 18(f), 6$ U.L.A. 213 (1969); CAL. CoRP. CODE $\S 15018(f)$ (West 1977).

158. 156 Cal. App. 3d 171, 203 Cal. Rptr. 13 (1984).

159. 459 S.W.2d 877 (Tex. Civ. App. 1970).

160. $156 \mathrm{Cal}$. App. 3d at 176, $203 \mathrm{Cal}$. Rptr. at 17.

161. UNIF. PARTNERShip ACT § 2, 6 U.L.A. 12 (1969) (emphasis added); CAL. Corp. CoDE $\S 15002$ (West 1960).

162. See, e.g., Cofer v. Hearne, 459 S.W.2d 877, 879 (Tex. Civ. App. 1970).

163. See, e.g., the lower court in Jewel v. Boxer reported by the appellate court at $156 \mathrm{Cal}$. App. 3d 171, 175-76, 203 Cal. Rptr. 13, 16 (1984); see also Lamb v. Wilson, 3 Neb. (Unof.) 496, 92 N.W. 167 (1902), rev'd on reh'g on other grounds, 3 Neb. (Unof.) 505, 97 N.W. 325 (1903); Cofer v. Hearne, 459 S.W.2d 877 (Tex. Civ. App. 1970). 
bing. And it is the legislature that is answerable to the taxpayers, who ultimately nust bear the increased costs associated with judicial oversight of a coinpensation scheine.

\section{CONCLUSION}

Currently, partnership dissolution is governed by the no-coinpensation rule. This rule requires that partners wind up the unfinished business for the benefit of the partnership. For these efforts, partners receive their partnership share, but no additional coinpensation. While the systein generally leads to equitable results, in the context of a law partnership, unfinished business necessarily nay be distributed unequally. Despite this inequity, the partners required to do the extra work are not entitled to extra coinpensation.

The no-compensation rule, while consistent with the policy against allowing dissolution for the purpose grabbing partnership assets, has negative effects as well. Partners wishing to dissolve in good faith may be discouraged from doing so if their winding-up burdens would be onerous relative to those of their partners. Thus, while the law generally favors at-will partnerships, the no-coinpensation rule may serve to lock partners into partnerships they would prefer to dissolve. Moreover, partners who in fact dissolve the partnership may refuse to coinplete inatters already begun, thereby preventing chients froin retaining the attorney of their choice.

This Comment has proposed the coinpensation inodel as an alternative. Under such a inodel, partners dissolving in good faith would be allowed compensation for their work to the extent that it was disproportionate to that of the other partners. The compensation would be a function of the expected value of the case at dissolution and the proportion of that value accruing after other partners have ceased winding up. This inodel decreases the effects of lock-in and lock-out without unacceptably increasing the potential for grabbing. While administering the proposed systein would involve costs in terms of judicial resources, the benefits of efficiently handling law partnership dissolutions outweigh these costs.

Mark H. Epstein* Brandon Wisoff**

* B.A. 1981, University of California, Los Angeles; J.D. 1985, Boalt Hall School of Law, University of California, Berkeley.

** B.A. 1980, University of California, Santa Cruz; J.D. 1985, Boalt Hall School of Law, University of California, Berkeley. 